\title{
Perceived Derived Attributes of Online Customer Reviews
}

\author{
Abdulaziz Elwalda, Brunel University London, Brunel Business School. \\ Email: Abdulaziz.Elwalda@brunel.ac.uk \\ Room: ESGW 001 \\ Brunel University \\ Uxbridge \\ UB8 3PH \\ United Kingdom \\ Tel: +44 (0)1895 265040
}

Kevin Lu*, Brunel University London, Brunel Business School.

Email: Kevin.lu@brunel.ac.uk

Room: ESGW 104c

Brunel University

Uxbridge

UB8 3PH

United Kingdom

Tel: +44 (0)1895 265254

* Corresponding author 


\section{Abstract}

The influence of online customer reviews (OCRs) on customers' purchase intention has recently gained considerable attention, in both academic and business communities. Technology allows customers to freely and easily post their comments and opinions online about any product or service; this type of customer review can have a significant effect on customers' purchase decisions. Previous studies, however, have mainly focused on the influence of the virtual attributes of OCRs such as volume and valence on consumers' intentions, while limited attention has been paid to understanding the effects of the derived attributes. This study, thus, aims to understand the impact of the perceived derived attributes of OCRs on customer trust and intention. This study develops a - Perceived Derived Attributes (PDA) - model, based on the inclusion of perceived control from the Theory of Planned Behaviour (TPB) with the Technology Acceptance Model (TAM), in order to investigate the effects of OCRs on customers' purchasing intention. A total of 489 responses to a survey were collected from users of amazon.com. The findings from this study suggest that customer trust in an e-vendor and their intention to shop online are significantly affected by perceived usefulness, perceived ease of use and perceived enjoyment of OCRs. Furthermore, the sense of control derived from OCRs significantly affects customer intention and significantly affects customer trust in e-vendors, particularly for customers who frequently check OCRs before making a purchase. Clearly, those attributes of OCRs are linked to the development of the shopping environment, which consequently can affect sales.

Keywords Online customer reviews (OCRs); electronic word-of-mouth (eWOM); TAM; Theory of Planned Behaviour (TPB); perceived enjoyment; perceived control. 


\section{Introduction}

Online customer reviews (OCRs) are a form of electronic word of mouth (eWOM) that refers to the user-generated contents that are posted on e-vendor websites or third-party websites (Mudambi \& Schuff, 2010). OCRs have become a key source of product information (Huang, Chen, Yen, \& Tran, 2015). Chen and Xie (2008) suggest that OCRs are a new element of the marketing communication mix. Firms have also started using them to understand customers' attitudes (Dellarocas et al., 2007).

OCRs are a rich source of product information. Customers tend to engage in reading online product information, as it assists customers in making the purchase decision (Cheung, Lee, \& Rabjohn, 2008). Given the trustworthiness and credibility of OCRs (Gruen, Osmonbekov, \& Czaplewski, 2006; Hu, Liu, Bose, \& Shen, 2010), a customer's adoption of the information provided by OCRs is likely to be a key factor affecting the customer's decision to purchase online. Previous studies (e.g. Chevalier \& Mayzlin, 2006; Flanagin \& Metzger, 2013; Huang et al., 2015; Lee \& Koo, 2015; Olbrich \& Holsing, 2012; Pan \& Zhang, 2011; Tirunillai \& Tellis, 2012) have mainly focused on the virtual attributes of OCRs such as volume, valence, variance and length (Elwalda and Lu, 2016; Moon et al., 2014). However, there are also derived attributes resulting from OCRs as a support tool for customers to make the purchasing decision.

What has not been adequately explained in the literature is the derived attributes of OCRs, such as usefulness, understandability, simplicity, enjoyment and sense of control (Liang, Ekinci, Occhiocupo, \& Whyatt, 2013; Yang, 2013). Unlike traditional WOM, eWOM is mediated by Internet technology; suggesting the significance of perceived factors (Sun, Youn, Wu, \& Kuntaraporn, 2006). Perceived derived attributes from OCRs are suggested to be a key factor in affecting customers' intention. Such importance of perceived derived attributes raises the need for investigating their effects on customer intention. Limited research has been reported on how these factors contribute to explaining customers' behavioural intention in the context of OCRs.

Hence, the present study aims to investigate and empirically test the effects of OCRs' derived attributes on customer trust and intention, as determined by perceived usefulness, perceived ease of use, perceived enjoyment and perceived control.

The present study contributes to the understanding of eWOM and OCRs' behaviour in several ways. Firstly, our study introduces a perceived derived attributes model (PDA) for understanding OCR behaviour, based on the inclusion of perceived control with the Technology Acceptance Model (TAM) model. The PDA model employs technology acceptance model (TAM), and theory of planned behaviour $(T P B)$ in order to investigate the role of the attribute resulting from OCRs. This is the first time that such an approach has been applied in the literature to understand the effects of the derived attributes of OCRs. The PDA model claims that the effects of OCRs are not only limited to the virtual attributes, such as volume and valance, but also that the perceived derived attributes of OCRs have an impact on customers' behaviour. We extend the TAM by arguing that the inclusion of perceived 
control from the Theory of Planned Behaviour (TPB) in the TAM is crucial when analysing the influence of eWOM.

Secondly, to the best of our knowledge, there is no study examining the impact of perceived usefulness, perceived ease of use, perceived enjoyment and perceived control derived from OCRs on customer trust and behavioural intention. The present study finds that customer trust in an e-vendor and customer intention to shop online are significantly affected by these perceived derived factors. The third contribution is that perceived control was employed in order to understand the effects that sense of control, derived from OCRs, has on customer trust and intention. The present study indicates that perceived control has a significant effect on customer intention to shop online. Additionally, the results reveal that for customers who frequently check OCRs before making a purchase, their trust in the e-vendor is significantly influenced by perceived control resulting from OCRs.

\section{Theoretical Background}

Online customer reviews (OCRs) have become a primary source of product information. This has resulted in them having a significant impact on consumer purchase decision making. However, previous investigations have mainly concerned with the virtual attributes of OCRs, such as, valance, volume, and variance. For example, Moe and Trusov (2011) indicate that the valence of OCRs has a direct influence on sales. Similarly, Floh, Koller, and Zauner (2013) find the intensity of the valence of OCRs has a significant effect on the sale of both books and hotels. Furthermore, Liu (2006) reveals that the volume of OCRs positively affects box office returns. On the other hand, the influence of OCRs is not only limited to the virtual attributes, but also to the derived attributes such as, perceived usefulness, perceived ease of use, perceived enjoyment, and perceived control that might significantly affect customers' behavioural intentions (Liang et al., 2013; Yang, 2013).

Perceived derived attributes form OCRs are suggested to be a main key affecting customers' intention. For example, perceived usefulness and ease of use were found to be an important antecedent in adopting eWOM (Hsu, Lin, \& Chiang, 2013; Liang et al., 2013; Yang, 2013). Furthermore, Park, Lee, and Hun (2007) report that the quality of the OCRs positively impact product sales. Also perceived ease of use was found to influence online trust (Aghdaie, Piraman, \& Fathi, 2011; Gefen, Karahanna, \& Straub, 2003). In addition, perceived enjoyment and perceived control have been established to be significant derived attributes from online discussion that affect intention (Van Dolen, Dabholkar, \& de Ruyter, 2007), and vital characteristics of Internet usage (Dabholkar, 1996; Davis, Bagozzi, \& Warshaw, 1992; Koufaris, 2002; Wolfinbarger \& Gilly, 2001).

Drawn from the Technology Acceptance Model (TAM) and the theory of Planned Behaviour (TPB), the present study introduces a "Perceived Derived Attributes" model (PDA) for investigating the behaviour of eWOM and OCRs. An integration of perceived usefulness, perceived ease of use, 
perceived enjoyment, and perceived control is applied to understand the effects of the derived attributes of OCRs on customer trust and purchase intentions.

\section{Technology Acceptance Model (TAM)}

The growth in virtual communities has empowered businesses to widen their interaction space with Internet users (Lin, 2007). As much as this interaction is social, it is mediated and supported by technology factors (Sun et al. 2006; Wang, Yu, \& Fesenmaier, 2002). Recently, the TAM has been employed in explaining the effect of information adoption in the context of eWOM (Ayeh, 2015; Casaló, Flavián, \& Guinalíu, 2010; Hsu et al., 2013; Liang et al., 2013; Yang, 2013). TAM has been accepted as a model to explain online customer behaviour (Gefen et al., 2003), and is broadly used for examining information technology adoption (Venkatesh, 2000). Additionally, previous studies have also indicated that eWOM has a significant influence on customers' intentions (Chen \& Xie, 2008; Clemons, Gao, \& Hitt, 2006; Godes \& Mayzlin, 2004).

TAM is a model developed to study the acceptance of the technology by individuals that explains how individuals come to accept and use a technology, originating from the theory of reasoned action. It is widely used to explain the adoption of new technology, underpinned by two constructs: "perceived usefulness" and "perceived ease of use". Davis et al. (1992) in an attempt to address TAM limitations in regard to its explanatory power (Bagozzi, 2007; Bhattacherjee \& Premkumar, 2004). Davis et al. (1992) report that perceived enjoyment has a significant impact on behavioural intention.

A theoretical background on the concepts of the three constructs of TAM (Perceived Usefulness, Perceived ease of Use and Perceived enjoyment is provided next.

\section{Perceived usefulness and perceived ease of use}

TAM suggests that perceived usefulness and perceived ease of use are the main determinants of system use and information adoption. Perceived usefulness is defined as "the degree to which a person believes that using a particular system would enhance his or her job performance" (Davis, 1989, p. 320). Perceived ease of use is defined as "the degree to which a person believes that using a particularly system would be free of effort" (Davis, 1989, p. 320). Employing these two definitions, this study refers to the perceived usefulness as the degree to which a customer believes that using OCRs enhances their online shopping experience. Perceived ease of use refers to the degree to which a customer believes that using OCRs is simple, and straightforward.

Drawing on TAM, Liang et al. (2013) studied international travellers' eWOM communication. Their study reveals that both perceived usefulness and perceived ease of use have a direct significant impact on overall attitude to adopting eWOM communication, while an indirect effect was observed for behavioural intention to use eWOM. Their findings also indicate that overall attitude towards eWOM communication partially mediates the relationship between the adoption of 
eWOM and the behavioural intention to use it. Taken together, these results suggest that customers are likely to use eWOM if the online information presented is useful and easy. Similarly, Casaló et al. (2010) indicate that participating in online travel communities is positively affected by their perceived usefulness. They also find that perceived ease of use influences both perceived usefulness and attitude towards participation in online travel communities. Furthermore, Lin (2007) surveyed the largest online communities in Taiwan and found that both technology acceptance factors have a positive significant influence on the sense of belonging to the virtual communities, leading to the purchase intention.

Using the review site Openrice.com, Yang (2013) finds that eWOM intention is mainly affected by the perceived usefulness of the website. Surprisingly, perceived ease of use, satisfaction and egoistic needs were found to have no impact on the dispersion of eWOM. However, the results indicate that perceived usefulness greatly moderates the relationship between satisfaction and egoistic needs, and engagement with eWOM communication. Yang (2013), on the other hand, attributes the non-significant effect of perceived ease of use on eWOM intention to the less complicated task that customers experience on the website Openrice.com. Customers can conventionally evaluate and rate their experience on Openrice.com. Moreover, the development of technology has eased the complex tasks of technology, weakening the effects of perceived ease of use. This is in line with the findings of Van Dolen et al. (2007), who establish that chat satisfaction in advisory group chats is not significantly influenced by ease of use. This was due to the experience and familiarity that respondents possess in online chat (Van Dolen et al., 2007).

In a different but related context, Hsu et al. (2013) examine the perceived usefulness of blogs for 327 blog readers. Perceived usefulness was independently constructed, with results indicating that the perceived usefulness of blogger recommendations has a great impact on both customer attitude and purchase intention. Interestingly, a recommendations' perceived usefulness is found to be influenced by trust in blogger recommendations; suggesting that the customer must first trust the recommendations in order for them to be perceived as useful.

\section{Perceived enjoyment}

Another major driver of new technology use and adoption is enjoyment (Davis et al. 1992; Lee, Cheung, \& Chen, 2005; Venkatesh, 2000). Perceived enjoyment is defined as "the extent to which the activity of using a specific system is perceived to be enjoyable in its own right, aside from any performance consequences resulting from system use" (Venkatesh, 2000, p. 351). This has led to the notion that enjoyment is an intrinsic driver (Lee et al. 2005). Previous studies on information systems have embraced perceived enjoyment as an intrinsic incentive to explain information technology (IT) system usage and adoption. In this regard, Davis et al. (1992) extend the original TAM by including perceived enjoyment as one of the main drivers for acceptance. Building on Davis et al. (1992), other researches have reported that a relationship exists between perceived enjoyment and behavioural 
intention; this relationship is a key aspect of online shopping. Indeed Ha and Stoel (2009) indicate that the likelihood of customers engaging in online shopping is greatly influenced by their enjoyment of the shopping process. Also, Li, Chua, and Lu (2005) find that the intention of using instant messaging is directly affected by the perceived enjoyment. Likewise, Koufaris (2002) reveals that perceived enjoyment has an impact on online customers' intention to return to the online shopping store.

Drawing on OCRs, perceived enjoyment refers to the extent to which a customer feels that OCRs are fun and entertaining. Researchers have highlighted the importance of enjoyment in the context of OCRs and eWOM. A study by Schindler and Bickart (2005) indicates that enjoyment is one of the top five reasons why individuals seek online messages. Similarly, Dholakia, Bagozzi, and Pearo (2004) note that individuals participate in virtual communities for three main reasons, one of which is enjoyment. Enjoyment is also found to be an important stimulus for engaging in eWOM (Cheung \& Lee, 2012; Okazaki, 2009). Phelps (2004), employing both a qualitative and quantitative approach, reveals that enjoyment is an essential driver for forwarding emails. Taking into account the significance of the perceived enjoyment of the online shopping experience and online reviews, the present study attempts to explain the effect that perceived enjoyment of OCRs has on customer trust and customer intention to use online shopping.

\section{Theory of Planned Behaviour (TPB)}

Theory of planned behaviour TPB was developed by Ajzen (1988). TPB relates beliefs to behaviour to enhance the predictive power of the theory of reasoned action by the inclusion of perceived control. TPB as constructed by attitude, subjective norms, and perceived behavioural control, predicts deliberate behaviour, since behaviour can be deliberative and planned (Ajzen, 1991). According to the $\mathrm{TPB}$, intentions can be only conveyed to the actual behaviour if that behaviour is only under an individual's perceived control (Ajzen, 1985; Madden et al., 1992). This study, thus, introduces the perceived derived attributes of OCRs by incorporating perceived control from TPB to the TAM to address the TAM limitations regarding the gap between intention and actual behaviour.

\section{Perceived control}

Perceived control refers to the level of control an individual has over their environment and actions (Hui \& Bateson, 1991; Koufaris, 2002). Perceived control has been examined in many different theoretical frameworks, for instance, in the Theory of Planned Behaviour (TPB) by Ajzen (1985, 1991), and Bandura's theory of self-efficacy (1982). The rationale behind the effect of perceived control on behaviour is that perceived control has a motivational influence over behavioural intention. When the level of control over accomplishing a specific behaviour is low, people's intention to accomplish that behaviour is likely to be low, even if a positive attitude is gained (Madden et al., 1992). 
In the present study, perceived control refers to the amount of control that a customer feels that OCRs provide during the process of online shopping. For online shopping, perceived control is not only considered as an interaction with the product itself, but rather as a consequence of the interaction behaviour with the website and its features (Koufaris, 2002). Unlike physical shopping, online shopping provides more information, leading to a higher efficiency and less effort; which ultimately results in demanding more control by customers (Jarvenpaa \& Todd, 1996). Using a qualitative approach, Wolfinbarger and Gilly (2001) find that obtaining buying information directly from a website, instead of having to go through a salesperson, increases customer's sense of control. The level of control obtained in the online shopping experience is derived from the lack of commitment that raises customers' efficiency, and diminishes the effort required for making a purchase (Wolfinbarger \& Gilly, 2001).

Previous studies have established the importance of perceived control for online shopping (Karjaluoto, Lehto, Leppäniemi, \& Jayewardene, 2008; Koufaris, 2002; Wang, 2014; Wolfinbarger \& Gilly, 2001). Wolfinbarger and Gilly (2001) highlight that finding the desired information on a website and following a system that allows information to be personalised, are likely to increase the level of perceived control. Similarly, Koufaris (2002) reports that a website's features, such as a recommendation system, help to increase the sense of control. Wolfinbarger and Gilly (2001), however, point out the difficulty of locating such information; hence, OCRs might be very helpful in this regard, as they are easily found and also provide credible information based on previous customers' evaluations and experiences. In turn, providing such a facility may increase the sense of control experienced by customers. Van Dolen et al. (2007) employ a structuration theory perspective to study online group chat. Their study reveals that customer satisfaction of group chat that leads to buying intention is significantly influenced by the perceived control acquired by customers in a group chat.

\section{Research Model (PDA)}

In this study we develop a new way of understanding the effects of OCRs on customers' behavioural intentions. Drawn from the technology of the acceptance model (TAM) and the Theory of Planned Behaviour (TPB), the present study introduces a perceived derived attributes model (PDA) for explaining eWOM and OCRs' behaviour. The PDA model is based on the inclusion of perceived control from TPB with TAM to understand the effects of OCRs' derived attributes on customer trust and intention

Although the TAM is a powerful model, it has been criticised for its limited explanatory power (Bagozzi, 2007; Bhattacherjee \& Premkumar, 2004). Particularly in the context of eWOM, where OCRs have a discrete nature, the TAM may not deliver satisfactory understanding of customer intentions (Ayeh, 2015). Moreover, previous research has highlighted a difference in the effects of 
perceived usefulness and ease of use between the pre-implantation stage and the post-implantation stage (Bhattacherjee \& Premkumar, 2004).

Addressing these limitations, Davis et al. (1992) extend the TAM model by introducing perceived enjoyment as an intrinsic motivation. Davis et al. (1992) find that perceived enjoyment has a significant impact on behavioural intention. Perceived enjoyment has been employed in different contexts: with the theory of reasoned action (Wu \& Liu, 2007); in an online shopping context (Wolfinbarger \& Gilly, 2001); and in eWOM research (Van Dolen et al., 2007). The present study overcomes the aforementioned limitations as it integrates perceived enjoyment as a predictor of intention with the original TAM. Secondly, the present study is only concerned with the perceived factors derived from OCRs. Furthermore, it studies the effect of OCRs on customer trust and intention in the pre-purchase stage. In other words, it examines how likely customers are to make a purchase after reading the reviews.

Nonetheless, the original TAM and its extensions fail to deal with the gap between intention and actual behaviour, as TAM particularly focuses on the usage, while neglecting the actual actions. Due to intentions being made prior to the actual behaviour, and as the time gap between the intention and behaviour potentially can be large, while also involving many required actions and decisions, and as intentions are often adjusted over a period of time, it is vital to consider the psychological and instrumental procedures between the intention and the actual behaviour (Bagozzi, 2007; Bagozzi \& Edwards, 1998).

According to the Theory of Planned Behaviour (TPB), intentions can be only transmitted to the actual behaviour if that behaviour is solely under an individual's perceived control (Ajzen, 1985; Madden, Ellen, \& Ajzen, 1992). An individual may desire to accomplish certain behaviour; however, they might not have the knowledge, opportunity or the necessary resources to actually perform it. TPB argues that perceived control is an exogenous variable that has a direct effect on behaviour and an indirect effect through behavioural intentions. The indirect influence is assumed to reflect the motivational implications that perceived control has on intentions, while the direct effect is based on the assumption that the individual has an actual control over the behaviour (Ajzen, 1991; Madden et al., 1992). In other words, perceived control affects both intentions and behaviour (Ajzen, 1991; Madden et al., 1992). Our study, hence, introduces the Perceived Derived Attributes (PDA) model by incorporating perceived control from TPB to the TAM to addresses the TAM limitations regarding the gap between intention and actual behaviour.

The PDA model is the first to explain the perceived derived attributes of OCRs, and to investigate the role of perceived control in eWOM communication. The PDA model shows that OCRs' influence is not only limited to the virtual attributes such as, volume and valence, but also to the derived attributes that may significantly affect customer behavioural intention. The PDA model delivers an understanding of the perceived derived attributes of OCRs; including perceived usefulness, preserved ease of use, perceived enjoyment, and perceived control. 


\section{Hypotheses development}

According to TAM, customer behaviour in an online context is determined by two main drivers involving perceived usefulness, and perceived ease of use (Davis, 1989; Vijayasarathy, 2004). Customers' intention of using a particular system is essentially caused by perceived usefulness and perceived ease of use. When customers identify that a specific system can improve their performance, they are more likely to adopt that system (Davis, 1989). In other words, if the system is useful, customers will have a positive attitude towards it and ultimately, will intend to use it. Perceived usefulness, thus, is related to the individual's intention. Consistence with this notion, findings from a Web survey of 932 Internet users indicates that there is a direct, positive relationship between perceived usefulness and behavioural intention (Ahn, Ryu, \& Han, 2004). This positive association has been confirmed by many other studies (Chen, Gillenson, \& Sherrell, 2002; Limayem, Khalifa, \& Frini, 2000; Trivedi \& Kumar, 2014).

The generalisability of much of the published studies on the effects of OCRs, have reported the significant impact of OCRs on customers' purchase intentions and sales (Clemons et al., 2006; Lu, Chang, \& Chang, 2014; Ye, Law, Gu \& Chen, 2011). Perceived usefulness in virtual communities comes from the belief that obtaining and sharing information with other customers enhances one's performance of using the system (Lin, 2007). Additionally, previous studies have highlighted the significant role of perceived usefulness in adopting eWOM and OCRs (Casaló et al., 2010; Liang et al., 2013). Moreover, Chen, Dhanasobhon, and Smith (2007) state that a relationship exists between helpful reviews on amazon.com and sales growth. Review quality was found to be an important dimension of the review usefulness (Cheung et al., 2008). In this regard, Park et al. (2007) reveal that sales of portable multimedia players are positively influenced by the quality of reviews. Furthermore, Hsu et al. (2013) highlight that the online shopping intentions of customers who read blogs are influenced by the perceived usefulness of the bloggers' recommendations. Mudambi and Schuff (2012) indicate that OCRs provide analytic value information throughout the various stages involved in the purchase decision. Building on these, the perceived usefulness of OCRs is likely to influence customers' intention to shop online. This study, therefore, proposes the following hypothesis:

Hypothesis 1: Perceived usefulness of OCRs has a positive impact on customers' intention to shop online.

Trust is a fundamental driver in participating in shopping in general, and particularly so in the online context (Gefen et al., 2003). McKnight and Chervany (2002) point out that trust in online shopping, is not just between customers and a website, but also between the system and customers. In other words, institutional trust is as important as interpersonal trust in the online setting, highlighting the importance of perceived usefulness and ease of use in such contexts. Even though some TAM studies have suggested that trust is affected by perceived ease of use, and is an antecedent of perceived 
usefulness (Gefen et al., 2003), others have concluded that both perceived usefulness and ease of use are antecedents of ecommerce trust ( Koufaris \& Hampton-Sosa, 2004). Awad and Ragowsky (2008), for instance, find that both the technology attributes of perceived usefulness and those of perceived ease of use have an impact on ecommerce trust. The absence of physical interaction in online shopping requires the e-vendor to provide the required cues to enhance customer trust (Ling, Daud, Piew, Keoy, \& Hassan, 2011). Useful, clear and easily understood information on websites are likely to decrease the confusion caused by asymmetric information and increase the trust in e-vendors (Lan $\&$ Chen, 2014). Also, Gefen et al. (2003) state that perceived ease of use may increase customer trust, with the perception that an e-vendor is exploiting on the buyer-seller relationship; indicating a relationship assurance.

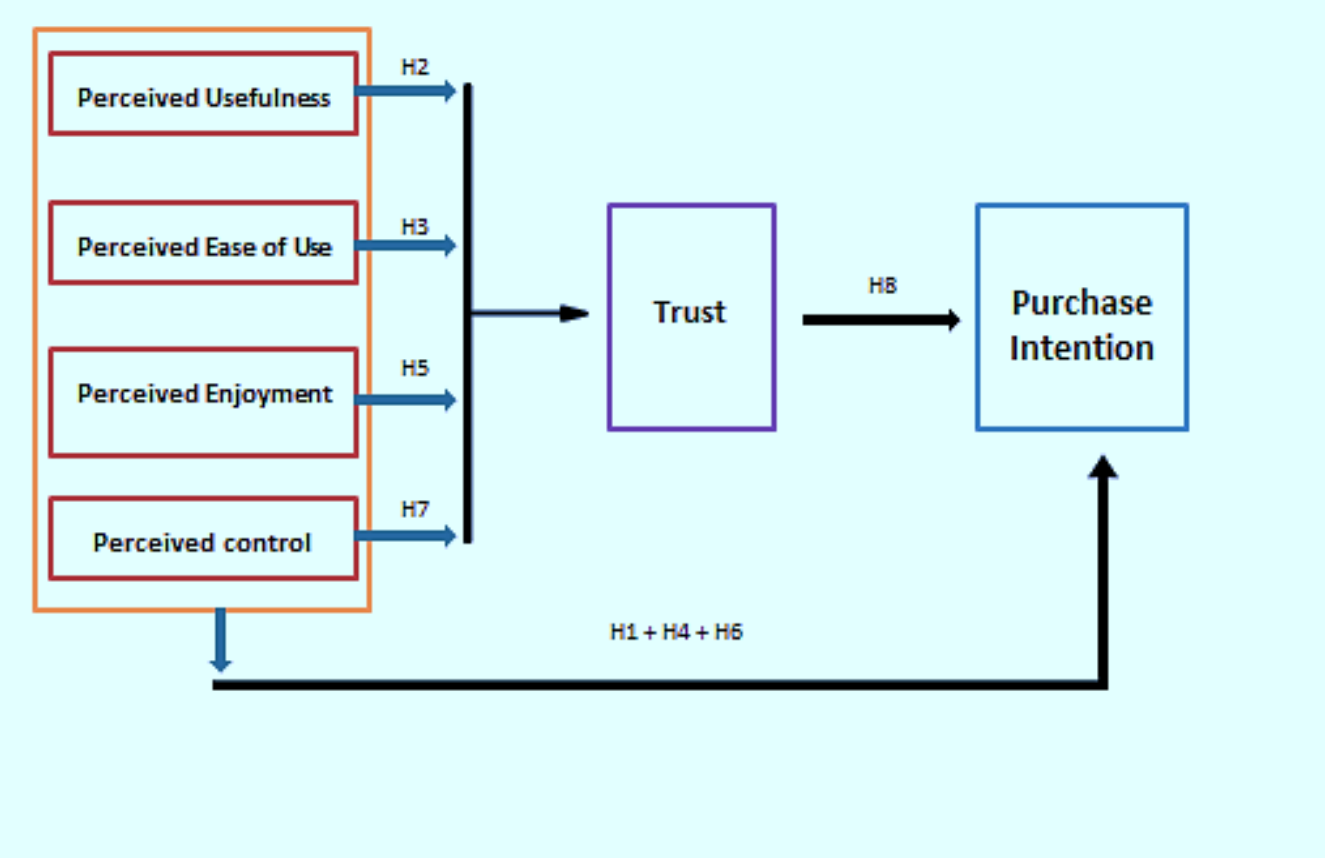

Figure 1: Perceived Derived Attributes model (PDA)

In relation to OCRs, prior researches have suggested that online review systems are generally employed to improve customer trust in e-vendors (Awad \& Ragowsky, 2008). Similarly, Chen, Wu, and Yoon (2004) argue that an increase in information sources may improve customer trust. According to an eMarketer report (2007), customers trust e-vendors that provide OCRs more than they trust other online sources. Firstly, OCRs are often provided voluntarily by customers; hence, creating a high level of trustworthiness and credibility (Hu et al., 2010). Moreover, Sen and Lerman (2007) demonstrate that customers have a tendency to trust OCRs, irrespective of their nature of being negative or positive. As reported by Zhao and Lavin (2012), trust is facilitated by knowledge transfer. 
OCRs as trusted sources of online information are likely to enhance customer trust in an e-vendor, by transferring customer knowledge and experience. Likewise, Hajli and Khani (2013) find that online communication through sharing experience and knowledge can build online trust. Secondly, review helpfulness was found to be related to product sales (Chen, Chang, and Yung 2007; Sen \& Lerman, 2007). It has been also reported that $97 \%$ of customers found online reviews to be accurate (Nunn, 2010). Jarvenpaa, Tractinsky, and Saarine (1999) indicate that the higher customer trust is, the more customers perceive the e-vendor's website to be useful. In this regard, Kumar and Benbasat (2006) established that the perceived usefulness of an e-vendor increases when OCRs are available. Xiaorong, Bin, Qinghong, Liuli and Yu (2011) also find that eWOM information has significant influence on customer trust. Given that the review system is deemed to be a useful and valuable part of a website and has an impact on customer intention; review usefulness may also influence customer trust. Finally, perceived ease of use of OCRs, as determined by their understandability and clearness is suggested to impact customer trust in the e-vendor (Gefen et al., 2003; Koufaris \& Hampton-Sosa, 2004). On the basis of these previous studies, this study proposes the following hypotheses:

Hypothesis 2: Perceived usefulness of OCRs has a positive effect on customer trust in evendors.

Hypothesis 3: Perceived ease of use of OCRs has a positive effect on customer trust in evendors.

Davis et al. (1992) extend the original TAM model to include perceived enjoyment. They argue that the acceptance of a system increases with enhanced enjoyment of using the system. In other words, the more enjoyable a system is, the higher the probability of accepting it will be. Their results indicate a significant impact of perceived enjoyment on behavioural intention. Interestingly, they observe a positive interaction between usefulness and enjoyment, suggesting that when a system is perceived to be more useful, perceived enjoyment has a greater impact on behavioural intention. The same outcome has also been reported by the studies that followed Davis et al. (1992). For instance, Teo, Lim, and Lai (1999) using data from 1,370 Internet users, find that perceived enjoyment strongly influences Internet usage. Perceived enjoyment is also found to be a strong motivation in the use of mobile services (Nysveen, Pedersen, \& Thorbjørnsen, 2005), to have a significant influence on intention to play online games (Wu \& Liu, 2007), and to greatly influence customers' engagement with online shopping (Ha \& Stoel, 2009). The enjoyment of blog usage, likewise, is found to positively affect tourists' behavioural intention to visit a destination (Chen, Shang, \& Li, 2014).

Furthermore, Reynolds and Maya (2013) state that perceived enjoyment has an impact on customers' revisit intention to the e-vendor's website. Moreover, in another examination by Koufaris (2002), enjoyment was found to significantly and directly affect repurchase intentions. The same findings were also obtained by another study (Bauer, Falk, \& Hammerschmidt, 2006) in which 
customers' intention to return is reported to be influenced by their perception of enjoyment. In addition, Van Dolen et al. (2007) conclude that perceived enjoyment of an online chat group affects users' satisfaction with the chat. Furthermore, enjoyment is reported to be one of the main key drivers for customers' participation in virtual communities and eWOM (Cheung \& Lee, 2012; Schindler \& Bickart, 2005). Accordingly, it can be argued that the enjoyable experience provided by OCRs will affect customers' intentions to shop online. This study, thus, proposes the following:

Hypothesis 4: Perceived enjoyment resulting from OCRs has a positive effect on customers' intentions to shop online.

Furthermore, enjoyment is considered to be a motivation that affects customers' online transactions (Chen \& Barnes, 2007). The cognitive perception of integrity that leads to trust is associated with the initial reaction of customers (Mattila \& Wirtz, 2000). Furthermore, flow theory proposes that a positive reaction such as enjoyment might boost more resources to deal with the concerned task (Agarwal \& Karahanna, 2000), suggesting that enjoyment may be connected to the ability aspect of ecommerce trust (Hwang \& Kim, 2007). Koufaris and Hampton-Sosa (2002) conducted an experimental study that demonstrated that a positive enjoyable experience with an e-vendor website enhances customer trust in the e-vendor through the perceived usefulness and ease of use of the website. Likewise, perceived enjoyment is found to influence website appeal, which significantly affects customer trust (Hampton-Sosa \& Koufaris, 2005). Moreover, Chen and Barnes (2007), using data from four online bookstores, reveal that enjoyment of technology is positively associated with customers' initial trust. The three attributes of ecommerce trust of integrity, benevolence and ability, have shown a tendency to be influenced by customers' perception of enjoyment (Chen \& Barnes, 2007). It is expected, therefore, that perceived enjoyment of OCRs impacts on customer trust. Accordingly, the following hypothesis is proposed:

Hypothesis 5: Perceived enjoyment resulting from OCRs has a positive effect on customers' trust in e-vendors.

According to the Theory of Planned Behaviour (TPB), perceived control refers to the necessary resources and opportunities for accomplishing a task (Ajzen, 1991). The greater the resources and support customers believe they possess, the greater the control they have over their behaviour. When customers believe that they possess a high degree of control over accomplishing a behaviour, because of the available resources, their ability to perform that behaviour increases (Madden et al., 1992). In this sense, OCRs as an additional resource of reliable information will increase a customer's sense of control over the online shopping process. Koufaris (2002), additionally, claims that the complex environment of online shopping has resulted in demands for more control by customers. Website features that would ease the customers' job of finding what they need, however, could overcome such issues. OCRs work in a way that helps customers to find what they are seeking by providing 
trustworthy information based on other customers' experiences (Gruen et al., 2006). Based on Koufaris's (2002) suggestions, OCRs could play a significant role in increasing the sense of customer control. Customers' ability to accomplish a task is greatly associated with their confidence in performing the task (Bandura, Adams, Hardy, \& Howells, 1980).

Moreover, prior research has revealed that perceived control has a significant influence on customer behaviour. For example, Wang, Chen et al. (2007), using data from both online and off online shoppers, find that the greater the customer's perception of control, the stronger the intention is to shop online will be. Their findings, interestingly, also show that the effect of perceived control is stronger than the effect of attitude on customer's intention to shop online. Similarly Nysveen et al. (2005), find that behavioural control has a strong impact on the intention to use mobile services. Wang (2010) also establishes that perceived control, in the E-tail context, positively affects online customers' intentions. Additionally, the intention to participate in permission-based mobile communications with a company appears to be influenced by individuals' perception of control (Karjaluoto et al., 2008). Furthermore, Chang (2008) reveals that satisfaction is related to perceived control, indicating that the higher the sense of control that customers possess, the greater their satisfaction will be. Besides, Wang (2014) finds that playing online games is positively and significantly influenced by the level of perceived control. Overall, these results suggest that perceived control is associated with customers' behavioural intention. In this study, thus, we propose the following hypothesis:

Hypothesis 6: Perceived control resulting from OCRs has a positive influence on customers' intention to shop online.

As previously mentioned, OCRs facility could possibly increase the sense of customer control as often they are easily found, are additional resources and offer trustworthy evaluation information (Van Dolen et al., 2007; Koufaris, 2002). Such a sense of control resulting from OCRs, may lead to an increase in customer trust in online shopping; as perceived control is considered to be an influential factor in the online trust setting (Eastlick, Lotz, \& Warrington, 2006). When the individuals have a high level of control over their actions, the level of insecurity and risk is likely to be reduced (Hampton-Sosa \& Koufaris, 2005). Bart et al. (2005), using data from 25 different websites, point out that website characteristics that are concerned with perceived control affect customer online trust. Hoffman, Novak, and Peralta (1999) highlight that customers' perception of control directly influences their online shopping security. This suggests that a high level of control over the online shopping process is likely to generate online trust. Consistent with this, Collier and Sherrell (2010) reveal that perceived control positively influences customer trust in service providers. Suh and Han (2003), collecting data from Internet banking users, also establish that the level of perceived control has a positive impact on ecommerce trust. Taken together, these results suggest that there is an 
association between the sense of control resulting from OCRs and customer trust in online shopping. Therefore, this study proposes the following:

Hypothesis 7: Perceived control resulting from OCRs positively impacts customer trust in the e-vendors.

Trust is generally defined as a belief (Hampton-Sosa \& Koufaris, 2005). Trust plays an important role in influencing customers' actions towards e-vendor websites (Hampton-Sosa \& Koufaris, 2005). Failing to provide a certain level of trustworthiness is likely to prevent customers from participating in online shopping, since customers are often anxious of e-vendor opportunistic behaviour (Hoffman et al., 1999). Once trust in an e-vendor is built, customers will form a positive belief towards online shopping, resulting in a purchase intention (Gefen et al., 2003). According to the TPB, customers' beliefs are important drivers for intentions to purchase (Ajzen, 1991). Thus, when customers believe that the e-vendor is trustworthy, they are likely to use an e-vendor's website to perform an online purchase (Hampton-Sosa \& Koufaris, 2005).

Previous investigations have exposed that trust is a significant antecedent of participating in online shopping (Gefen et al., 2003; Gefen \& Straub, 2004; Pavlou, 2003). Kim, Ferrin, and Rao (2008) reveal that customers' behavioural intentions regarding online shopping are strongly affected by Internet trust. Likewise, in Taiwan, trust is found to positively affect nurses' intentions to use an electronic logistics information system (Tung, Chang, \& Chou, 2008). Xiaorong et al. (2011) find that trust originating from eWOM information, has a significant positive effect on customers' intentions. Ling et al. (2011) establish that customer trust significantly and positively affects customers' engagement in online activities in Singapore. In addition, Shukla (2014) using a self-administered structured questionnaire, finds that online trust positively influences customer purchase intentions. In another examination by Hsu et al. (2013), trust is also found to have a positive significant impact on blog readers to shop online. It is therefore suggested that customers who trust e-vendors that provide OCRs are more likely to make a purchase. Consequently, this study, proposes the following:

Hypothesis 8: Trust in e-vendors who provide OCRs has a positive impact on customers' intentions to shop online.

\section{Methodology}

\section{Research design}

In order to understand the effects of OCRs' derived factors on customer trust and intention, a focus group and a paper-based survey were conducted. According to Remenyi, Williams, and Money (1998), using mixed methods is a suitable method in management and business studies. Similarly, Bryman (2003) argues that using both qualitative and quantitative techniques enhances research 
reliability. Additionally, because of the compatibility between qualitative and quantitative approaches, employing tools from both approaches is considered to be appropriate (Howe, 1988).

A focus group was first formed to examine the rationality and suitability of the research model. The research model was discussed in great detail, which resulted in a better and deeper understanding of the individuals' views of OCRs' derived attributes. The feedback and suggestions from the focus group were merged into the proposed model and were used to form the design of the survey.

Secondly, the initial questionnaire was constructed based on the research model with consideration of the related literature. The questionnaire asked participants to answer sets of questions based on a five-point Likert scale (strongly disagree to strongly agree). The questionnaire consists of six variables: perceived usefulness, perceived ease of use, perceived enjoyment, perceived control, customer trust, and purchase intention. In addition, four demographic questions (age, gender, education, and profession) and three questions on online behaviour (Internet use, online shopping use, and posting behaviour) were asked.

To fulfil the study's aim, a measurement scale was adopted and modified to the context of this study. Measurements for perceived usefulness and perceived ease of use were adopted from Gefen et al. (2003) and Koufaris (2002). Perceived enjoyment and perceived control were assessed by adopting the scale used by Van Dolen et al. (2007). Measurements for trust were adopted from Lee and Turban (2001). Finally, purchase intention was measured by adopting measurements from Gefen et al. (2003) and Hsu et al. (2013). Summary of measurement scales is presented in table 1.

\section{Pre-test and pilot test}

Both a pre-test and a pilot test were employed to test whether the items of the questionnaire actually measure the study' constructs. The pre-test involved eight participants, who frequently post and read online reviews and shop online at least four times a month, being asked to provide feedback on the questionnaire. The following areas of the questionnaire were evaluated: content, format, wording and length.

A pilot test was then conducted in order to check the suitability of the questionnaire on a small sample, representing the main study population. A total of 49 responses were collected. Coefficient alpha (Cronbach's alpha) and item-to-total correlations were applied to test the reliability of the instrument (Churchill, 1979). Nunnally (1978) proposes that a score of 0.5 to 0.6 is acceptable to ensure the item's reliability. All the constructs, however, achieved a Cronbach's alpha score of greater than 0.7. In addition, item-to-total correlations were used to test the relationship between particular items in the same set.

Based on the participants' feedback from the pre-test and pilot test, several questions were modified. The final questionnaire consisted of 24 questions, representing demographic information and the six variables previously mentioned. 


\begin{tabular}{|c|c|c|}
\hline Construct & Item & Source \\
\hline \multirow{3}{*}{$\begin{array}{l}\text { Perceived } \\
\text { usefulness }\end{array}$} & $\begin{array}{l}\begin{array}{l}\text { Online customer reviews } \\
\text { effectiveness }\end{array} \\
\text { efhance }\end{array}$ & \multirow{3}{*}{$\begin{array}{l}\text { Gefen et al. (2003) } \\
\text { and Koufaris (2002) }\end{array}$} \\
\hline & $\begin{array}{l}\text { Online customer reviews increase my effectiveness when shopping } \\
\text { online }\end{array}$ & \\
\hline & I find using online customer reviews useful & \\
\hline \multirow{3}{*}{$\begin{array}{l}\text { Perceived ease of } \\
\text { use }\end{array}$} & Online customer reviews services are not confusing & \multirow{3}{*}{$\begin{array}{l}\text { Gefen et al. (2003) } \\
\text { and Koufaris (2002) }\end{array}$} \\
\hline & $\begin{array}{l}\text { Online customer reviews services do not take a lot of time as a } \\
\text { customer }\end{array}$ & \\
\hline & $\begin{array}{l}\text { My interaction with online customer reviews is manageable and } \\
\text { understandable }\end{array}$ & \\
\hline \multirow{3}{*}{$\begin{array}{l}\text { Perceived } \\
\text { enjoyment }\end{array}$} & $\begin{array}{l}\text { I find the experience of reading online customer reviews is } \\
\text { enjoyable }\end{array}$ & \multirow{3}{*}{$\begin{array}{l}\text { Van Dolen et al. } \\
\text { (2007) }\end{array}$} \\
\hline & $\begin{array}{l}\text { I find the experience of reading online customer reviews is } \\
\text { pleasant }\end{array}$ & \\
\hline & Online customer reviews are interesting & \\
\hline \multirow[t]{3}{*}{ Perceived control } & $\begin{array}{l}\text { I feel more in control of online shopping when using online } \\
\text { customer reviews }\end{array}$ & \multirow{3}{*}{$\begin{array}{l}\text { Van Dolen et al. } \\
\text { (2007) }\end{array}$} \\
\hline & $\begin{array}{l}\text { Through online customer reviews, I have a direct influence on } \\
\text { finding the information I need }\end{array}$ & \\
\hline & $\begin{array}{l}\text { Online customer reviews enable me to obtain on the necessary } \\
\text { information }\end{array}$ & \\
\hline \multirow[t]{3}{*}{ Trust } & $\begin{array}{l}\text { Shopping from e-vendors that provide online customer reviews is } \\
\text { unreliable }\end{array}$ & \multirow[t]{3}{*}{ Lee \& Turban (2001) } \\
\hline & $\begin{array}{l}\text { Shopping from e-vendors that provide online customer reviews } \\
\text { cannot be trusted; there are just too many uncertainties }\end{array}$ & \\
\hline & $\begin{array}{l}\text { In general, I cannot rely on an Internet vendor that provides } \\
\text { online customer reviews to keep the promises they make }\end{array}$ & \\
\hline \multirow[t]{3}{*}{ Purchase intention } & $\begin{array}{l}\text { I strongly recommend others should shop from e-vendors that } \\
\text { provide online customer reviews }\end{array}$ & \multirow{3}{*}{$\begin{array}{l}\text { Gefen et al. (2003) } \\
\text { and Hsu et al. (2013) }\end{array}$} \\
\hline & $\begin{array}{l}\text { I would be willing to provide my credit card details when } \\
\text { purchasing from an online retailer that provides online customer } \\
\text { reviews }\end{array}$ & \\
\hline & $\begin{array}{l}\text { I would be willing to provide information to an online retailer } \\
\text { that provides online customer reviews }\end{array}$ & \\
\hline
\end{tabular}

Table 1. Summary of measurement scales

\section{Sample}

Date was collected from users of amazon.com in London. Amazon was chosen as it is a leading and successful online retailer, in which, arguably, its OCRs facility are regarded as its most powerful features (Chen \& Xie 2008). The data collection process took eight weeks, in which 515 responses were received, creating a response rate of $41.2 \%, 489$ of which were deemed to be useable. Descriptive statistics show that $52.8 \%$ of the respondents were male and $47.2 \%$ were female, and they were aged $19-46$ years. More than $83 \%$ of the participants have a university degree or higher. The majority of the respondents (i.e. $82.8 \%$ ) have more than six years' experience with using the Internet and possess an acceptable familiarity with posting and reading OCRs.

\section{Data analysis and results}

\section{Descriptive statistics}

The descriptive statistics show generally positive responses by the participants to the constructs of the framework, as all means were greater than 3.0. The descriptive statistics also illustrate that all constructs have a small standard deviation score, suggesting that the data are clustered around the 
mean, signifying that the data is reliable. Means and standard deviations of the constructs are illustrated in Table 2.

\begin{tabular}{|lcccccccc|} 
Construct & $N$ & Mean & Median & SD & Cronbach's $\alpha$ & Skewness & Kurtosis \\
\hline $\begin{array}{l}\text { Perceived usefulness } \\
\text { Perceived ease of }\end{array}$ & 489 & 3.68 & 3.67 & 0.71 & 0.752 & -0.404 & 0.949 \\
\hline $\begin{array}{l}\text { use } \\
\text { Perceived }\end{array}$ & 3.44 & 3.33 & 0.71 & 0.789 & -0.315 & 0.006 \\
enjoyment & 489 & 3.30 & 3.33 & 0.80 & 0.846 & -0.476 & 0.33 \\
\hline Perceived control & 489 & 3.45 & 3.33 & 0.71 & 0.799 & -0.068 & -0.029 \\
\hline Trust in e-vendor & 489 & 3.42 & 3.67 & 0.76 & 0.730 & -0.223 & 0.011 \\
\hline Purchase intention & 489 & 3.29 & 3.33 & 0.70 & 0.822 & -0.616 & 0.659 \\
\hline
\end{tabular}

Table 2. Descriptive statistics

\section{Normality, reliability and validity}

First, the data was checked for normality. Skewness and kurtosis tests were employed. Results show that the data is in the acceptable range for skewness and kurtosis (i.e. $\leq 2.58$ ) (Hair, Black, Babin, \& Anderson, 2010). Moreover, the graphical analysis shows similar scores among the mean and median, suggesting that the data is normally distributed.

Following the normality check, the Kaiser-Meyer-Olkin (KMO) and principal component factor analysis were employed to assess sample adequacy and scale validity. A KMO value of 0.787 was obtained, indicating that the sample is appropriate for conducting principal component factor analysis. The principal component factor analysis was applied to all six constructs, using the rotation method of Varimax with Kaiser Normalization. Convergent validity reflecting the items' association with the variables was first assessed. The intra-correlations among theoretically comparable items were strong. Discriminant validity, on the other hand, showed each variable's items to be unique and that they do not interfere with other variables. Moreover, taking into account the large sample and the low correlation between different variables, multicollinearity issues are removed (Field, 2005). Six components were extracted, each with an absolute value greater than 0.4. All items were loaded onto each specific variable, explaining $71.9 \%$ of the total variance. In addition, as can be seen from Table 3 , all items showed high factor loadings between 7.30 and 8.70, and each item presented a higher loading on its equivalent variable than other variables, suggesting that satisfactory validity of convergent and discriminant validity were met.

Cronbach's alpha was used to assess the scales' reliability. All of the scales achieved a score of greater than 0.7, which meets Nunnally's (1978) suggestions for acceptable reliability. The reliability scores are shown in Table 2 . 


\begin{tabular}{|c|c|c|c|c|c|c|}
\hline Items & & & & onents & & \\
\hline & 1 & 2 & 3 & 4 & 5 & 6 \\
\hline $\begin{array}{l}\text { Online customer reviews enhance my online } \\
\text { shopping effectiveness }\end{array}$ & 0.831 & & & & & \\
\hline $\begin{array}{l}\text { Online customer reviews increase my effectiveness } \\
\text { when shopping online }\end{array}$ & 0.777 & & & & & \\
\hline I find using online customer reviews useful & 0.729 & & & & & \\
\hline Online customer reviews services are not confusing & & 0.792 & & & & \\
\hline $\begin{array}{l}\text { Online customer reviews services do not take a lot of } \\
\text { time as a customer }\end{array}$ & & 0.827 & & & & \\
\hline $\begin{array}{l}\text { My interaction with online customer reviews is } \\
\text { manageable and understandable }\end{array}$ & & 0.789 & & & & \\
\hline $\begin{array}{l}\text { I find the experience of reading online customer } \\
\text { reviews is enjoyable }\end{array}$ & & & 0.870 & & & \\
\hline $\begin{array}{l}\text { I find the experience of reading online customer } \\
\text { reviews is pleasant }\end{array}$ & & & 0.864 & & & \\
\hline Online customer reviews are interesting & & & 0.797 & & & \\
\hline $\begin{array}{l}\text { I feel more in control of online shopping when using } \\
\text { online customer reviews }\end{array}$ & & & & 0.784 & & \\
\hline $\begin{array}{l}\text { Through online customer reviews, I have a direct } \\
\text { influence on finding the information I need }\end{array}$ & & & & 0.791 & & \\
\hline $\begin{array}{l}\text { Online customer reviews enable me to obtain the } \\
\text { necessary information }\end{array}$ & & & & 0.720 & & \\
\hline $\begin{array}{l}\text { Shopping from e-vendors that provide online } \\
\text { customer reviews is unreliable }\end{array}$ & & & & & 0.877 & \\
\hline $\begin{array}{l}\text { Shopping from e-vendors that provide online } \\
\text { customer reviews cannot be trusted; there are just } \\
\text { too many uncertainties }\end{array}$ & & & & & 0.842 & \\
\hline $\begin{array}{l}\text { In general, I cannot rely on an Internet vendor that } \\
\text { provides online customer reviews to keep the } \\
\text { promises they make }\end{array}$ & & & & & 0.787 & \\
\hline $\begin{array}{l}\text { I strongly recommend others should shop from e- } \\
\text { vendors that provide online customer reviews }\end{array}$ & & & & & & 0.745 \\
\hline $\begin{array}{l}\text { I would be willing to provide my credit card details } \\
\text { when purchasing from an online retailer that } \\
\text { provides online customer reviews }\end{array}$ & & & & & & 0.818 \\
\hline $\begin{array}{l}\text { I would be willing to provide information to an } \\
\text { online retailer that provides online customer } \\
\text { reviews }\end{array}$ & & & & & & 0.731 \\
\hline
\end{tabular}

Table 3: Rotated component matrix

\section{Measurement model}

Confirmatory factor analysis (CFA) was used to assess measurement properties of scales. A standardised loading of at least 0.62 was recorded for all items, with a significant loading on their particular variable (Hair et al., 2010). Composite reliability (CR) was employed to measure the internal consistency reliability of the survey. Consistent with Hair et al. (2010) and Nunnally (1994), all variable scored a composite reliability of greater than 0.7 . Average variance expected (AVE), that is the explained average variance of an item's loading (Hair et al., 2010), results showed that the six variables were $\geq 0.5$ (Fornell \& Larcker, 1981). Item loading, Composite reliability (CR) and Average variance expected (AVE) are shown in table 4. 


\begin{tabular}{|c|c|c|c|c|}
\hline Construct & Item & Loadings & $C R$ & $A V E$ \\
\hline \multirow[t]{3}{*}{ Perceived usefulness } & PU1 & 0.84 & \multirow[t]{3}{*}{0.754} & \multirow[t]{3}{*}{0.510} \\
\hline & PU2 & 0.64 & & \\
\hline & PU3 & 0.65 & & \\
\hline \multirow[t]{3}{*}{ Perceived ease of use } & PEOU1 & 0.69 & \multirow[t]{3}{*}{0.803} & \multirow[t]{3}{*}{0.578} \\
\hline & PEOU2 & 0.73 & & \\
\hline & PEOU3 & 0.84 & & \\
\hline \multirow[t]{3}{*}{ Perceived enjoyment } & PE1 & 0.79 & \multirow[t]{3}{*}{0.788} & \multirow[t]{3}{*}{0.553} \\
\hline & PE2 & 0.73 & & \\
\hline & PE3 & 0.79 & & \\
\hline \multirow[t]{3}{*}{ Perceived control } & PC1 & 0.74 & \multirow[t]{3}{*}{0.814} & \multirow[t]{3}{*}{0.594} \\
\hline & $\mathrm{PC} 2$ & 0.75 & & \\
\hline & PC3 & 0.74 & & \\
\hline \multirow[t]{3}{*}{ Trust } & $\mathrm{T} 1$ & 0.95 & \multirow[t]{3}{*}{0.867} & \multirow[t]{3}{*}{0.687} \\
\hline & $\mathrm{T} 2$ & 0.75 & & \\
\hline & T3 & 0.73 & & \\
\hline \multirow[t]{3}{*}{ Purchase intention } & PI1 & 0.74 & \multirow[t]{3}{*}{0.730} & \multirow[t]{3}{*}{0.500} \\
\hline & PI2 & 0.62 & & \\
\hline & PI3 & 0.70 & & \\
\hline
\end{tabular}

Table 4. Item loading, composite reliability (CR) and average variance expected (AVE)

Table 5 shows that the square root of the AVE is greater than any other correlations among the variables, suggesting that the variables are different and discriminant validity is met. Such results reconfirm the convergent and discriminant validity of the measurement scales.

\begin{tabular}{|lllllll|}
\hline & PU & PEOU & PE & PC & T & PI \\
\hline PU & $\mathbf{0 . 7 1 4}$ & & & & & \\
\hline PEOU & 0.211 & $\mathbf{0 . 7 6 0}$ & & & & \\
\hline PE & 0.344 & 0.304 & $\mathbf{0 . 7 7 1}$ & & & \\
\hline PC & 0.558 & 0.460 & 0.485 & $\mathbf{0 . 7 4 4}$ & & \\
\hline T & 0.271 & 0.406 & 0.280 & 0.284 & $\mathbf{0 . 8 2 9}$ & \\
\hline PI & 0.537 & 0.275 & 0.466 & 0.444 & 0.305 & $\mathbf{0 . 6 9 0}$ \\
\hline
\end{tabular}

Table 5. A factor correlation matrix with the square root of the AVE

\section{Model fit and hypothesis testing}

Structural equation modelling (SEM) using AMOS 20.0.0 was employed to assess the hypothesised theoretical model. Firstly, the structural model fit was evaluated. Chi-square results $\left(x^{2}(144 \mathrm{df})=\right.$ $381.789)(p<0.0001)$ suggest that the model fit is unsatisfactory. Chi-square statistics, however, are very sensitive to the sample size (Hair et al., 2010); therefore, it is an inadequate index in this study to reject the model. Thus, the following statistics were selected to determine the structural model's fit: Goodness-of-Fit Index (GFI), Adjusted Goodness-of-Fit Index (AGFI), Normed Fit Index (NFI), Tucker-Lewis Index (TLI), Comparative Fit Index (CFI), Root Mean Square Error of Approximation (RMSEA), and Root Means Square Residual (RMR) (Hair et al., 2010). GFI, CFI, NFI, AGFI and 
TLI values of between 0.8 and 0.89 are considered to be a reasonable fit, while values between 0.9 and 1.0 are considered to be a good fit. RMSEA values less than 0.05 are considered to be a good fit, and values between 0.06 and 0.08 are considered as an acceptable fit. RMR values of less than 0.08 are preferred (Hair et al., 2010; MacCallum, Browne, \& Sugawara, 1996). Indices results show that $\mathrm{GFI}=0.922, \mathrm{AGFI}=0.884, \mathrm{CFI}=0.924, \mathrm{NFI}=0.90, \mathrm{TLI}=0.90, \mathrm{RMSEA}=0.069$, and $\mathrm{RM}=0.032$, which suggests that the model fit is acceptable (Hair et al., 2010). Model fit indices are presented in table 6.

\begin{tabular}{|cccccccccc|} 
Index & $\mathbf{x}^{2}$ & DF & GFI & AGFI & CFI & NFI & TLI & RMSEA & RMR \\
\hline Score & 381.789 & 144 & 0.922 & 0.884 & 0.924 & 0.90 & 0.90 & 0.069 & 0.032 \\
\hline
\end{tabular}

Table 6. Model fit indices

As expected in H1, the perceived usefulness of OCRs has a positive significant effect on customers' intention to shop online. The results support H1 $(\beta=0.35, \mathrm{p}<0.001)$ suggesting that customer intention to shop with e-vendors is affected by the usefulness of customer reviews provided. The findings also support $\mathrm{H} 2(\beta=0.17, \mathrm{p}<0.009)$ indicating that perceived usefulness of OCRs significantly impacts customers' trust in the e-vendor. Moreover, perceived ease of use of OCRs has a significant influence on customers' trust in the e-vendor $(\beta=0.35, \mathrm{p}<0.001)$; hence, supporting H3.

$\mathrm{H} 4$ regards that the enjoyment resulting from OCRs has a positive significant impact on customers' intentions to shop online. The results support $\mathrm{H} 4(\beta=0.22, \mathrm{p}<0.001)$, suggesting that enjoyment plays an important role in affecting customers' decision to shop online. Likewise, the effects of perceived enjoyment of OCRs on customers' trust in the e-vendor was significant ( $\beta=0.14$, $\mathrm{p}<0.020)$; therefore, H5 is supported. 


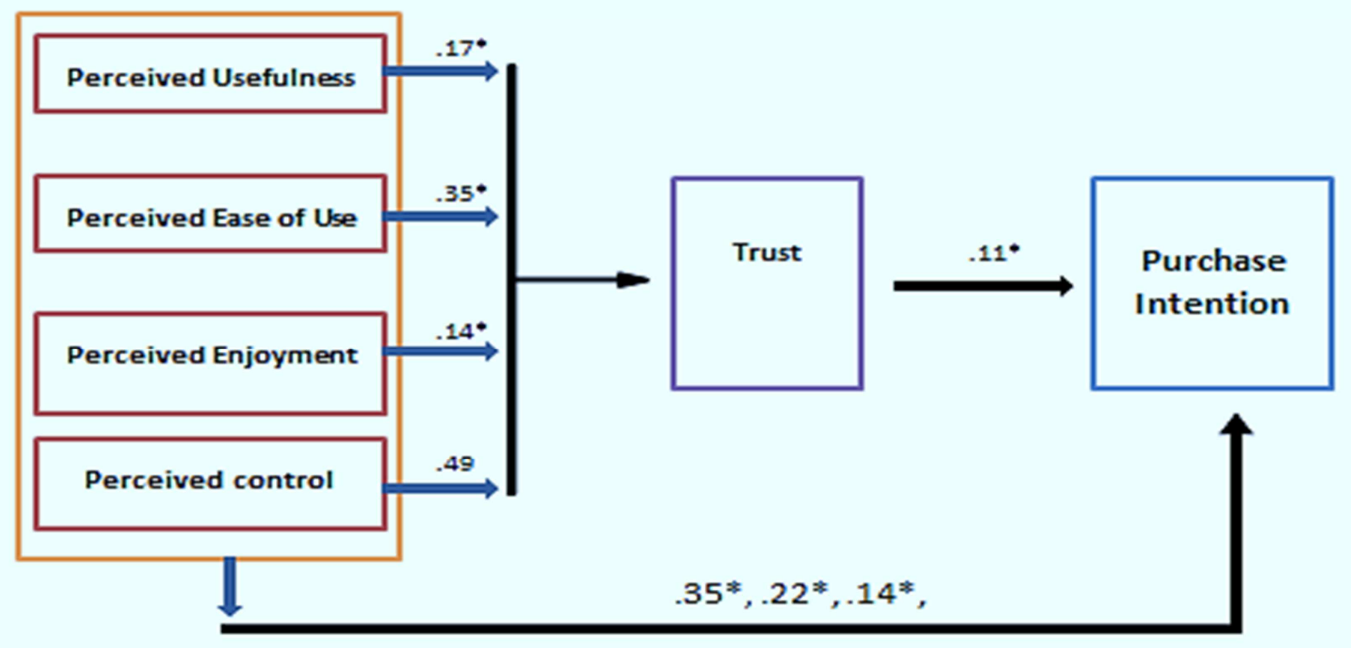

Figure 2: PDA model: results of structural modelling analysis. * Significant.

Furthermore, perceived control derived from OCRs has a significant impact on customers' intention to shop online, supporting H6 $(\beta=0.14, \mathrm{p}<0.05)$. Perceived control resulting from OCRs had a positive effect on customer trust in the e-vendor. Unexpectedly, this effect was insignificant; however, when the sample was further categorised according to the participants' review reading behaviour, it was found that customers' trust is affected by the perceived control of OCRs for those customers who frequently read OCRs before making a purchase $(\beta=0.352, \mathrm{p}<0.001)$. On the other hand, perceived control had no significant impact on customer trust for customers who "sometimes or never" check the OCRs before making a purchase. Finally, supporting H8, trust in the e-vendor, unsurprisingly was found to have a significant influence on customers' intention to shop online ( $\beta=$ $0.11, \mathrm{p}<0.009)$. Table 7 shows a summary of hypothesis assessment.

\begin{tabular}{|llllll|}
\hline No. & Research hypothesis & S. & P value & Results & Effect \\
H1 & $\begin{array}{l}\text { Perceived usefulness of OCRs has a } \\
\text { significant impact on customers } \\
\text { intention to shop online }\end{array}$ & 0.35 & $0 . .001$ & Supported & Significant \\
\hline H2 & $\begin{array}{l}\text { Perceived usefulness of OCRs has a } \\
\text { significant impact on customer trust } \\
\text { in e-vendors }\end{array}$ & 0.17 & 0.009 & Supported & Significant \\
\hline H3 & $\begin{array}{l}\text { Perceived ease of use of OCRs has a } \\
\text { Percenty }\end{array}$ & 0.35 & 0.001 & Supported & Significant \\
\hline
\end{tabular}




\begin{tabular}{|c|c|c|c|c|c|}
\hline & $\begin{array}{l}\text { significant impact on customer trust } \\
\text { in e-vendors }\end{array}$ & & & & \\
\hline H4 & $\begin{array}{l}\text { Perceived enjoyment, resulting from } \\
\text { OCRs, has a significant impact on } \\
\text { customers' intentions to shop online }\end{array}$ & 0.22 & 0.001 & Supported & Significant \\
\hline H5 & $\begin{array}{l}\text { Perceived enjoyment, resulting from } \\
\text { OCRs, has a significant impact on } \\
\text { customers' trust in an e-vendor }\end{array}$ & 0.14 & 0.020 & Supported & Significant \\
\hline H6 & $\begin{array}{l}\text { Perceived control, resulting from } \\
\text { OCRs, has a significant impact on } \\
\text { customers' intention to shop online }\end{array}$ & 0.14 & 0.050 & Supported & Significant \\
\hline \multirow[t]{3}{*}{ H7 } & $\begin{array}{l}\text { Perceived control, resulting from } \\
\text { OCRs, has a significant impact on } \\
\text { customer trust in the e-vendor. }\end{array}$ & .049 & 0.070 & Rejected & Insignificant \\
\hline & $\begin{array}{l}\text {...... people who always read the review } \\
\text { before making a purchase }\end{array}$ & 0.35 & 0.001 & Supported & Significant \\
\hline & $\begin{array}{l}\text {....... people who "sometimes, never" } \\
\text { read the review before making a purchase }\end{array}$ & 0.05 & .060 & Rejected & Insignificant \\
\hline H8 & $\begin{array}{l}\text { Trust in e-vendors who provide } \\
\text { OCRs has a significant impact on } \\
\text { customers' intentions to shop online }\end{array}$ & 0.11 & 0.009 & Supported & Significant \\
\hline
\end{tabular}

Table 7. Hypothesis assessment

\section{Discussion}

This study investigates the influence of the usefulness, ease of use, enjoyment and control factors of OCRs on customer trust and purchasing intention. Understanding the effects of such influencing factors is of importance for both theoretical development and business practices. The present study introduces the perceived derived attributes model (PDA) in order to provide greater insight on the impact of OCRs on customer behaviour. This study extends the TAM by the inclusion of perceived control from the Theory of Planned Behaviour (TPB), and applies the research of TAM to the OCRs context. In addition, the findings show that the perceived derived attributes of OCRs significantly influence customers' trust in the e-vendor and their intentions to shop online.

The study indicates that the perceived usefulness of OCRs has a significant direct influence on customer purchase intention. Previous work such as David (1989), Gefen et al. (2003), Limayem et al. (2000), and Pavlou (2003), reports that perceived usefulness strongly affects customers' intention to shop online. The present study expands these works to establish that customers' purchase intention 
is significantly affected by the perceived usefulness derived from OCRs. Furthermore, while Liang et al. (2013) demonstrate that the adoption of eWOM, as determined by its usefulness, positively affects customer behavioural intention, our study demonstrates that perceived usefulness derived from OCRs is a main vital element that directly affects customers' intentions to shop online. Similar to OCRs, a study of recommendations provided by blogs, shows that their perceived usefulness significantly affects customers' intention to purchase (Hsu et al., 2013). The results of our study, therefore, confirm previous studies and highlight the potential importance of the perceived usefulness of OCRs in affecting customers' intentions to purchase online, signifying that e-vendors should allow customers to post reviews on their websites.

The findings also show that the perceived usefulness and perceived ease of use of OCRs are important antecedents of trust in the online context. Whereas Awad and Ragowsky (2008) find that perceived usefulness and ease of use of an online retailer's website have a positive influence on online trust in general, our findings establish that perceived usefulness and ease of use derived from OCRs significantly affect trust in the e-vender itself. The usefulness of OCRs as determined by enhancing a customer's online shopping effectiveness and increasing their shopping efficiency, boosts the level of trust in the e-vendor. Interestingly, this suggests that e-vendors who provide OCRs seem to be trustworthy, regardless of whether the reviews are positive or negative. In contrast to some eWOM research that has argued that some positive or negative reviews might be harmful for sales (Schindler \& Bickart, 2005; Standifird, 2001), our study reveals that OCRs, irrespective of their content, could still be useful and may possibly increase customers' trust in an e-vendor. Moreover, the significant effect of the perceived ease of use of OCRs on customer trust proposes that any easily understandable interaction between a customer and an e-vendor's website created by OCRs could build trust in the evendor. Additionally, the findings support previous studies in the online shopping context, where Gefen et al. (2003) and Tung et al. (2008) find that ecommerce trust is affected by perceived usefulness and ease of use.

This study also indicates that perceived enjoyment resulting from OCRs significantly affects customers' intention to shop online. Enjoyment was found to be a key driver impacting customer purchase intentions (Davis et al., 1992; Ha \& Stoel, 2009; Koufaris, 2002; Teo et al., 1999). Our findings, however, expands the existing work (Davis et al., 1992; Ha \& Stoel, 2009; Koufaris, 2002; Teo et al., 1999) to suggest that the element of enjoyment in OCRs is an important motive for customers to shop online. The more enjoyable the OCRs are, the more likely the customer will engage in online shopping. Interestingly, this study also shows that perceived enjoyment resulting from OCRs boosts customers' trust in an e-vendor. The relationship between enjoyment and customer trust is significant. Customers seem to trust e-vendors who provide OCRs that have the element of enjoyment. This result matches those observed in an earlier study by Koufaris and Hampton-Sosa (2002), who notice that an enjoyable experience with the e-vendor improves customer trust. Such an 
enjoyable experience could be derived by reading OCRs (Van Dolen et al., 2007), which is likely to result in increasing trust in the e-vendor.

In addition, perceived control resulting from OCRs was conceptualised as affecting customer's behavioural intention and trust. A major theoretical result of this study relates to perceived control, as it was proposed that perceived control was part of a TAM model. The findings reveal that the sense of control resulting from OCRs can influence customers' intention to shop online. In other words, the higher the sense of control provided by the OCRs, the more likely a customer is to make an online purchase. The results particularly highlight the importance of the control perception in the context of eWOM. Studies by Wang et al. (2007) and Nysveen et al. (2005) show that the perception of control has a strong effect on customer intention. The results of our study, however, strongly suggest that the presence of perceived control in a TAM model helps to provide a better understanding of customer behavioural intention online.

Contrary to expectations, this study did not find a significant effect of perceived control derived from OCRs on customer trust in the e-vendor. Previous studies have reported that perceived control has an impact on trust (Collier \& Sherrell, 2010). A possible explanation for the lack of support for this hypothesised relationship between control and trust may be due to the level of control provided by OCRs being insufficient to influence customers' trust in the e-vendor. As trust leads to intention (Gefen et al., 2003; Pavlou, 2003), it seems possible that the level of perception of control required to influence trust is greater than the level required to influence intention to purchase. This might explain why perceived control resulting from OCRs influences customers' intentions but not their trust. However, categorising the sample into further groups according to their behaviour in relation to reading reviews surprisingly generated interesting results. The findings reveal that perceived control derived from OCRs, for customers who frequently read OCRs before making an online purchase, has a significant effect on their trust in the online vendors. On the other hand, for customers who do not often read OCRs before making a purchase, their trust is not influenced by their perception of control. One possible explanation of the observed associations might be related to the possession of information. The more information customers have the more control they possess over their online shopping process (Madden et al., 1992). Hence, this could lead to greater trust for those who always read OCRs as they have more information. Also, as OCRs are usually perceived to provide trustworthy information (Wolfinbarger \& Gilly, 2001) customers who always read OCRs should have more trust in an e-vendors that allow OCRs on their website.

Finally, the study found that trust significantly impacts customers' intention to shop online. This finding mirrors those of previous studies that examined the effect of trust on behavioural intention (Gefen et al., 2003; Lan \& Chen, 2014; Ling et al., 2011; Pavlou, 2003; Pavlou \& Gefen, 2004; Zhou, 2012). Our outcomes clearly confirm that trust is a key antecedent of customer intention in online shopping. When the e-vendor is perceived to be trustworthy, customers are more likely to perform an online purchase. 


\section{Conclusions}

This study proposed a research model called Perceived Derived Attributes (PDA), which addresses the issues of the perceived derived attributes of OCRs. The focus of the PDA model was to address the research question, which is 'What are the effects of the perceived derived attributes of OCRs on customer trust and purchase intention?' The PDA model argues that the perceived derived attributes of OCRs have an impact on customer trust and intentions. Principally, the PDA model claims that the perceived usefulness, perceived ease of use, perceived enjoyment, and perceived control positively affect customer trust in the e-vendor and customer intentions to shop online. The PDA model was validated through a survey of 489 users of amazon.com.

The results revealed that perceived derived attributes from OCRs play an important role in affecting customer behaviour. This study established that customer purchase intentions are significantly affected by the perceived usefulness and the perceived ease of use derived from OCRs. Additionally, the perceived usefulness and the perceived ease of use derived from OCRs are important antecedents of trust in an online context. The study's results also revealed that the perceived enjoyment resulting from OCRs significantly affects customer trust and customer intentions to shop online. Interestingly, the results also show that customers seem to trust e-vendors who provide OCRs that have the element of enjoyment, suggesting enjoyment as a key factor affecting customer trust.

The perceived control resulting from OCRs was hypothesised to influence customers' behavioural intentions and customer trust. The results indicated that the sense of control resulting from OCRs affects customers' intentions to shop online. Surprisingly, the results showed no significant effect of perceived control derived from OCRs on customer trust in the e-vendor. However, when the sample was further grouped according to customers' behaviour in relation to reading reviews surprisingly generated interesting results. The results showed that perceived control derived from OCRs, for customers who frequently read OCRs before making an online purchase, has a significant effect on their trust in the online vendors. On the other hand, for customers who do not often read OCRs before making a purchase, their trust is not affected by their perception of control resulting from OCRs.

The results of this study offer several theoretical implications that add to the literature in many influential ways. First, this study introduces the Perceived Derived Attributes (PDA) model, which integrates perceived control from TPB with TAM for understanding the effects of OCRs. To the best of our knowledge, this is the first attempt to introduce and investigate the effects of the attributes resulting from OCRs. It extends the TAM by arguing that the inclusion of perceived control from the TPB in the TAM is vital when analysing the effects of OCRs and eWOM. The PDA model claims that the effects of OCRs are not only limited to the virtual attributes, such as volume and valance, but also that the perceived derived attributes of OCRs have an impact on customers' behaviour.

Moreover, to the extent of our knowledge, there is no study investigating the influence of perceived usefulness, perceived ease of use, perceived enjoyment and perceived control derived from 
OCRs on customer trust and behavioural intention. This study found that these four functional attributes resulting from OCRs have an impact on customer trust and intentions to shop online.

Additionally, the findings from this study suggest several meaningful implications for managers that could possibly enhance the relationship and communication between e-vendors and customers, build trust and ultimately boost sales for e-vendors.

Firstly, with regard to the general implications, this study shows that OCRs play an important role, affecting customer trust and intention, suggesting that e-vendors need to allow customers to post reviews on their websites. Additionally, the perceived usefulness, ease of use, enjoyment, and control of OCRs have been empirically shown to have a significant effect on customers' intention to shop online. OCRs, hence, appear to provide a useful facility for e-vendors for increasing sales. Thus, evendors may encourage customers to post reviews on their websites and to participate more in eWOM. E-vendors, through OCRs, can influence customer's decisions and intentions.

Furthermore, trust in e-vendors can be built by providing OCRs. The attributes of OCRs as being useful, clear, understandable, pleasant and enjoyable, are key drivers for developing customer trust. Therefore, posting reviews that hold such attributes should be encouraged. Even though some of these reviews might be negative, the results show that regardless of the nature of the reviews, OCRs can still be beneficial for e-vendors. For instance, previous research on eWOM proposes that evendors should embrace online reviews rather than fear them (Burton \& Khammash, 2010). The experience of reading the reviews on an e-vendor's website seems to have a great impact on customers; hence, this could be considered by e-vendors in their marketing strategies. To stimulate such attributes in OCRs, certain tools may be installed within the review system.

Moreover, results indicate that the element of enjoyment in OCRs is very important in building trust and influencing customers' intention to shop online. It appears that online shoppers are interested in enjoyment factors while online shopping. As OCRs might provide an enjoyable experience (Van Dolen et al., 2007), e-vendors should work in a way that improves the online shopping experience. In the context of OCRs, this can be achieved, for example, by creating an enjoyable atmosphere for the OCR service or by interacting more often with customer's reviews.

The results of this study also highlight the role of perceived control in influencing customers' trust in e-vendors. OCRs provide a sense of control that results in increased trust in e-vendors, especially for customers who frequently read OCRs before purchasing. Thus, e-vendors might develop a tool to stimulate customers to frequently read the online reviews on their websites. Evendors also could hire communication advisors who may improve customers' interaction with the reviews.

Finally, the findings reveal that online shoppers tend to trust e-vendors who provide OCRs, which in turn affects customers' decision to purchase. It is vital, therefore, for e-vendors to benefit from the communication provided by OCRs and enhance it in a way that ensures the above-mentioned attributes are included. 


\section{Limitations and future research}

The study offers an understanding of the effects of OCRs on customer trust and intention; however, the generalisability of the study's results is subject to certain limitations. Firstly, the sample was selfselected from users of amazon.com. In addition, 52.8\% of the sample were aged 18 to 25 years and $83 \%$ were well educated. Hence, future study could use a larger data set with different demographic groups. Secondly, the framework was tested on those customers who shop online at amazon.com, therefore, applying this framework to other e-vendors who specialise in similar products such as clothes and electronics, is recommended. Furthermore, the study was conducted in the UK. Shopping lifestyle and culture might vary among countries; hence, it is suggested to test the framework in different countries. Moreover, a questionnaire method was deemed to be suitable for this study. A controlled experiment might further be used in the future research to test the proposed model. Finally, the inclusion of other variables, for instance, OCRs' credibility, similarity and social support into the study framework might verify the model's validity. 


\section{References}

Agarwal, R., \& Karahanna, E. (2000). Time flies when you're having fun: Cognitive absorption and beliefs about information technology usage. MIS quarterly, 24(4). Retrieved from http://www.jstor.org/stable/3250951

Aghdaie, S. F. A., Piraman, A., \& Fathi, S. (2011). An Analysis of factors affecting the consumer's Attitude of trust and their impact on internet purchasing behavior. International Journal of Business and Social Science, 2(23), 147-158. Retrieved from http://www.ijbssnet.com/journals/Vol_2_No_23_Special_Issue_December_2011/16.pdf

Ahn, T., Ryu, S., \& Han, I. (2004). The impact of the online and offline features on the user acceptance of Internet shopping malls. Electronic Commerce Research and Applications, 3(4), 405-420. doi:10.1016/j.elerap.2004.05.001

Ajzen, I. (1985). From intentions to actions: A theory of planned behavior. In Action control: From cognition to behavior, (pp. 11-39) Springer Berlin Heidelberg. doi:10.1007/978-3-642-697463_2

Ajzen, I. (1988). Attifudes, personality, and behavior. Chicago: Dorsey Press.

Ajzen, I. (1991). The theory of planned behavior. Organizational behavior and human decision processes, 50(2), 179-211. doi:10.1016/0749-5978(91)90020-T

Awad, N. F., \& Ragowsky, A. (2008). Establishing trust in electronic commerce through online word of mouth: an examination across genders. Journal of Management Information Systems, 24(4), 101-121. doi:10.2753/MIS0742-1222240404

Ayeh, J. K. (2015). Travellers' acceptance of consumer-generated media: An integrated model of technology acceptance and source credibility theories. Computers in Human Behavior, 48, 173180. doi:10.1016/j.chb.2014.12.049

Bagozzi, R., \& Edwards, E. (1998). Goal setting and goal pursuit in the regulation of body weight. Psychology \& Health, 13, 593-621. doi:10.1080/08870449808407421

Bagozzi, R. P. (2007). The Legacy of the technology acceptance model and a proposal for a paradigm shift . Journal of the Association for Information Systems, 8(4), 244-254. Retrieved from http://search.proquest.com/docview/198793649

Bandura, A. (1982). Self-efficacy mechanism in human agency. American psychologist, 37(2), 122. doi: 10.1037/0003-066X.37.2.122

Bandura, A., Adams, N. E., Hardy, A. B., \& Howells, G. N. (1980). Tests of the generality of selfefficacy theory. Cognitive therapy and research, 4(1), 39-66. doi:10.1007/BF01173354

Bauer, H. H., Falk, T., \& Hammerschmidt, M. (2006). eTransQual: A transaction process-based approach for capturing service quality in online shopping. Journal of Business Research, 59(7), 866-875. doi:10.1016/j.jbusres.2006.01.021

Bhattacherjee, A., \& Premkumar, G. (2004). Understanding changes in belief and attitude toward information technology usage: a theoretical model and longitudinal test. MIS quarterly, 28(2) 229-254. Retrieved from http://www.jstor.org/stable/25148634

Bryman, A. (2003). Quantity and quality in social research. Routledge, New York, NY 
Burton, J., \& Khammash, M. (2010). Why do people read reviews posted on consumer-opinion portals? Journal of Marketing Management, 26(3-4), 230-255.

doi:10.1080/02672570903566268

Casaló, L. V, Flavián, C., \& Guinalíu, M. (2010). Determinants of the intention to participate in firmhosted online travel communities and effects on consumer behavioral intentions. Tourism Management, 31(6), 898-911. doi:10.1016/j.tourman.2010.04.007

Chang, C.-C. (2008). Choice, perceived control, and customer satisfaction: The psychology of online service recovery. CyberPsychology \& Behavior, 11(3), 321-328. doi:10.1089/cpb.2007.0059

Chatterjee, P. (2001). Online reviews : Do Consumers use them?. Advances in consumer research 28, 129-134. Retrieved from http://www.acrwebsite.org/search/view-conferenceproceedings.aspx $? \mathrm{Id}=8455$

Chen, L., Gillenson, M. L., \& Sherrell, D. L. (2002). Enticing online consumers: an extended technology acceptance perspective. Information \& management, 39(8), 705-719. doi:10.1016/S0378-7206(01)00127-6

Chen, P., Dhanasobhon, S., \& Smith, M. D. (2007). An analysis of the differential impact of reviews and reviewers at Amazon. com. In Proceedings of the 28th International Conference on Information Systems. Association for information system, Montreal. 1-17.

Chen, P.-Y., Wu, S., \& Yoon, J. (2004). The Impact of Online Recommendations and Consumer Feedback on Sales. In Twenty-Fifth International Conference on Information Systems. Association for information system, Washington DC (pp. 711-723). Retrieved from http://aisel.aisnet.org/cgi/viewcontent.cgi?article=1146\&context=icis2004

Chen, Y., \& Xie, J. (2008). Online consumer review: word-of-mouth as a new element of marketing communication mix. Management Science, 54(3), 477-491. doi:10.1287/mnsc.1070.0810

Chen, Y.-H., \& Barnes, S. (2007). Initial trust and online buyer behaviour. Industrial Management \& Data Systems, 107(1), 21-36. doi:10.1108/02635570710719034

Chen, Y. C., Shang, R. A., \& Li, M. J. (2014). The effects of perceived relevance of travel blogs' content on the behavioral intention to visit a tourist destination. Computers in Human Behavior, 30, 787-799. doi:10.1016/j.chb.2013.05.019

Cheung, C. M. K., \& Lee, M. K. O. (2012). What drives consumers to spread electronic word of mouth in online consumer-opinion platforms. Decision Support Systems, 53(1), 218-225. doi:10.1016/j.dss.2012.01.015

Cheung, C. M. K., Lee, M. K. O., \& Rabjohn, N. (2008). The impact of electronic word-of-mouth: The adoption of online opinions in online customer communities. Internet Research, 18(3), 229247. doi:10.1108/10662240810883290

Chevalier, J. A., \& Mayzlin, D. (2006). The effect of word of mouth on sales: online book reviews. Journal of Marketing Research, 43(3), 345-354. Retrieved from http://www.jstor.org/stable/30162409

Churchill Jr, G. A. (1979). A paradigm for developing better measures of marketing constructs. Journal of Marketing Research, 16(1), 64-73. Retrieved from http://www.jstor.org/stable/3150876 
Clemons, E., Gao, G., \& Hitt, L. (2006). When online reviews meet hyperdifferentiation: A study of the craft beer industry. Journal of Management Information Systems, 23(2), 149-171. doi:10.2753/MIS0742-1222230207

Collier, J. E., \& Sherrell, D. L. (2010). Examining the influence of control and convenience in a selfservice setting. Journal of the Academy of Marketing Science, 38(4), 490-509. doi: 10.1007/s11747-009-0179-4

Dabholkar, P. A. (1996). Consumer evaluations of new technology-based self-service options: an investigation of alternative models of service quality. International Journal of research in Marketing, 13(1), 29-51. doi:10.1016/0167-8116(95)00027-5

Davis, F. D. (1989). Perceived usefulness, perceived ease of use, and user acceptance of information technology. MIS quarterly, 13(3), 319-340. Retrieved from http://www.jstor.org/stable/249008

Davis, F. D., Bagozzi, R. P., \& Warshaw, P. R. (1992). Extrinsic and intrinsic motivation to use computers in the workplace1. Journal of Applied Social Psychology, 22(14), 1111-1132. doi: 10.1111/j.1559-1816.1992.tb00945.x

Dellarocas, C., Zhang, X. (Michael), \& Awad, N. F. (2007). Exploring the value of online product reviews in forecasting sales: The case of motion pictures. Journal of Interactive Marketing, 21(4), 23-45. doi:10.1002/dir.20087

Dholakia, U. M., Bagozzi, R. P., \& Pearo, L. K. (2004). A social influence model of consumer participation in network-and small-group-based virtual communities. International Journal of Research in Marketing, 21(3), 241-263.doi: 10.1016/j.ijresmar.2003.12.004

Eastlick, M. A., Lotz, S. L., \& Warrington, P. (2006). Understanding online B-to-C relationships: an integrated model of privacy concerns, trust, and commitment. Journal of Business Research, 59(8), 877-886. doi: 10.1016/j.jbusres.2006.02.006

Elwalda, A. and Lu, K. (2016), "The impact of online customer reviews (OCRs) on sales: an exploration of the main dimensions of OCRs", Journal of Customer Behaviour. (In Press)

eMarketer.com., Online review sway shoppers, Retrieved from

http://www.emarketer.com/Article.aspx?R=10064042008Last accessed. 18/12/2013

Flanagin, A. J., \& Metzger, M. J. (2013). Trusting expert-versus user-generated ratings online: The role of information volume, valence, and consumer characteristics. Computers in Human Behavior, 29(4), 1626-1634. doi:10.1016/j.chb.2013.02.001

Field, A. (2005). Discovering statistics using SPSS for windows: Advanced techniques for beginners, introducing statistical methods series, SAGE Publications Ltd, London.

Floh, A., Koller, M., \& Zauner, A. (2013). Taking a deeper look at online reviews: the asymmetric effect of valence intensity on shopping behaviour. Journal of Marketing Management, 29(5-6), 646-670. doi:10.1080/0267257X.2013.776620

Fornell, C., \& Larcker, D. F. (1981). Evaluating structural equation models with unobservable variables and measurement error. Journal of Marketing Research (JMR), 18(1). Retrieved from http://www.jstor.org/stable/3151312

Gefen, D., Karahanna, E., \& Straub, D. W. (2003). Inexperience and experience with online stores: the importance of TAM and trust. Engineering Management, IEEE Transactions on, 50(3), 307321. doi:10.1109/TEM.2003.817277 
Gefen, D., \& Straub, D. W. (2004). Consumer trust in B2C e-Commerce and the importance of social presence: experiments in e-Products and e-Services. Omega, 32(6), 407-424. doi:10.1016/j.omega.2004.01.006

Godes, D., \& Mayzlin, D. (2004). Using online conversations to study word-of-mouth communication. Marketing Science, 23(4), 545-560. doi:10.1287/mksc.1040.0071

Gruen, T. W., Osmonbekov, T., \& Czaplewski, A. J. (2006). eWOM: the impact of customer-tocustomer online know-how exchange on customer value and loyalty. Journal of Business Research, 59(4), 449-456. doi:10.1016/j.jbusres.2005.10.004

Ha, S., \& Stoel, L. (2009). Consumer e-shopping acceptance: antecedents in a technology acceptance model. Journal of Business Research, 62(5), 565-571. doi:10.1016/j.jbusres.2008.06.016

Hair, J. F., Black, W. C., Babin, B. J., \& Anderson, R. E. (2010). Multirative Data Analysis: A Global Perspective. Pearson Prentice Hall, New Jersey.

Hajli, M., \& Khani, F. (2013). Establishing Trust in Social Commerce through Social Word of Mouth. International Journal of Information Science and Management (IJISM), 39-53. In e-Commerce in Developing Countries: With Focus on e-Security (ECDC), 2013 7th International Conference on (pp. 1-22). IEEE.

Hampton-Sosa, W., \& Koufaris, M. (2005). The effect of web site perceptions on initial trust in the owner company. International Journal of Electronic Commerce, 10(1), 55-81. Retrieved from http://www.ijec-web.org/

Hoffman, D. L., Novak, T. P., \& Peralta, M. (1999). Building consumer trust online. Communications of the ACM, 42(4), 80-85. doi:10.1145/299157.299175

Howe, K. R. (1988). Against the quantitative-qualitative incompatibility thesis or dogmas die hard. Educational researcher, 17(8), 10-16. Retrieved from http://www.jstor.org/stable/1175845

Hsu, C.-L., Lin, J. C.-C., \& Chiang, H.-S. (2013). The effects of blogger recommendations on customers' online shopping intentions. Internet Research, 23(1), 69-88. doi:10.1108/10662241311295782

Hu, N., Liu, L., Bose, I., \& Shen, J. (2010). Does sampling influence customers in online retailing of digital music? Information Systems and E-Business Management, 8(4), 357-377. doi:10.1007/s10257-009-0116-6

Huang, A. H., Chen, K., Yen, D. C., \& Tran, T. P. (2015). A study of factors that contribute to online review helpfulness. Computers in Human Behavior, 48, 17-27. doi:10.1016/j.chb.2015.01.010

Hui, M. K., \& Bateson, J. E. G. (1991). Perceived control and the effects of crowding and consumer choice on the service experience. Journal of Consumer Research, 18(2), 174-184. Retrieved from http://www.jstor.org/stable/2489553

Hwang, Y., \& Kim, D. J. (2007). Customer self-service systems: The effects of perceived Web quality with service contents on enjoyment, anxiety, and e-trust. Decision Support Systems, 43(3), 746760. doi:10.1016/j.dss.2006.12.008

Jarvenpaa, Sirkka L., Tractinsky, N., \& Saarinen, L. (1999). Consumer trust in an Internet store: a cross-cultural validation. Journal of Computer-Mediated Communication, 5(2), 0. doi:10.1111/j.1083-6101.1999.tb00337.x 
Jarvenpaa, Sirrka L., \& Todd, P. A. (1996). Consumer reactions to electronic shopping on the World Wide Web. International Journal of electronic commerce, 1(2), 59-88. Retrieved from http://www.jstor.org/stable/27750810

Karjaluoto, H., Lehto, H., Leppäniemi, M., \& Jayawardhena, C. (2008). Exploring gender influence on customer's intention to engage permission-based mobile marketing. Electronic markets, 18(3), 242-259. doi:10.1080/10196780802265793

Kim, D. J., Ferrin, D. L., \& Rao, H. R. (2008). A trust-based consumer decision-making model in electronic commerce: The role of trust, perceived risk, and their antecedents. Decision Support Systems, 44(2), 544-564. doi:10.1016/j.dss.2007.07.001

Kim, J. B. (2012). An empirical study on consumer first purchase intention in online shopping: integrating initial trust and TAM. Electronic Commerce Research, 12(2), 125-150. doi:10.1007/s10660-012-9089-5

Koufaris, M. (2002). Applying the technology acceptance model and flow theory to online consumer behavior. Information systems research, 13(2), 205-223. doi:10.1287/isre.13.2.205.83

Koufaris, M., \& Hampton-Sosa, W. (2002). Customer trust online: examining the role of the experience with the Web-site. Department of Statistics and Computer Information Systems Working Paper Series, Zicklin School of Business, Baruch College, New York.

Koufaris, M., \& Hampton-Sosa, W. (2004). The development of initial trust in an online company by new customers. Information \& Management, 41(3), 377-397. doi:10.1016/j.im.2003.08.004

Kumar, N., \& Benbasat, I. (2006). The influence of recommendations and consumer reviews on evaluations of websites. Information Systems Research, 17(4), 425-439.

doi:10.1287/isre.1060.0107

Lee, K. T., \& Koo, D. M. (2015). Evaluating right versus just evaluating online consumer reviews. Computers in Human Behavior, 45, 316-327. doi:10.1016/j.chb.2014.12.036

Lee, M. K. O., Cheung, C. M. K., \& Chen, Z. (2005). Acceptance of Internet-based learning medium: the role of extrinsic and intrinsic motivation. Information \& management, 42(8), 1095-1104. doi:10.1016/j.im.2003.10.007

Lee, M. K. O., \& Turban, E. (2001). A trust model for consumer Internet shopping. International Journal of electronic commerce, 6(1), 75-91. doi:10.1080/10864415.2001.11044227

Lee, M., \& Youn, S. (2009). Electronic word of mouth (eWOM): How eWOM platforms influence consumer product judgement. International Journal of Advertising, 28(3), 473. doi:10.2501/S0265048709200709

Li, D., Chua, P. Y. K., \& Lu, H. (2005). Understanding Individual Adoption of Instant Messaging: An Empirical Investigation. Journal of the Association for Information Systems, 6(4). Retrieved from http://stu.hksyu.edu/ wkma/notes/jour395/li_chau_lou2005.pdf

Liang, S. W.-J., Ekinci, Y., Occhiocupo, N., \& Whyatt, G. (2013). Antecedents of travellers' electronic word-of-mouth communication. Journal of Marketing Management, 29(5-6), 584606. doi:10.1080/0267257X.2013.771204

Liao, C., Palvia, P., \& Chen, J.-L. (2009). Information technology adoption behavior life cycle: toward a technology continuance theory (TCT). International Journal of Information Management, 29(4), 309-320. doi:10.1016/j.ijinfomgt.2009.03.004 
Limayem, M., Khalifa, M., \& Frini, A. (2000). What makes consumers buy from Internet? A longitudinal study of online shopping. Systems, Man and Cybernetics, Part A: Systems and Humans, IEEE Transactions on, 30(4), 421-432. doi:1083-4427(00)05143-2

Lin, H.-F. (2007). The role of online and offline features in sustaining virtual communities: an empirical study. Internet Research, 17(2), 119-138. doi: 10.1111/j.1083-6101.2004.tb00229.x

Ling, K. C., bin Daud, D., Piew, T. H., Keoy, K. H., \& Hassan, P. (2011). Perceived risk, perceived technology, online trust for the online purchase intention in Malaysia. International Journal of Business and Management, 6(6), p167. doi:10.5539/ijbm.v6n6p167

Liu, Y. (2006). Word of mouth for movies: Its dynamics and impact on box office revenue. Journal of Marketing, 70(3), 74-89. Retrieved from http://www.jstor.org/stable/30162102

Lu, L. C., Chang, W. P., \& Chang, H. H. (2014). Consumer attitudes toward blogger's sponsored recommendations and purchase intention: The effect of sponsorship type, product type, and brand awareness. Computers in Human Behavior, 34, 258-266. doi:10.1016/j.chb.2014.02.007

MacCallum, R. C., Browne, M. W., \& Sugawara, H. M. (1996). Power analysis and determination of sample size for covariance structure modeling. Psychological methods, 1(2), 130. doi: 10.1037/1082-989X.1.2.130

Madden, T. J., Ellen, P. S., \& Ajzen, I. (1992). A comparison of the theory of planned behavior and the theory of reasoned action. Personality and Social Psychology Bulletin, 18(1), 3-9. doi:10.1177/0146167292181001

Mattila, A., \& Wirtz, J. (2000). The role of preconsumption affect in postpurchase evaluation of services. Psychology and Marketing, 17(7), 587-605. doi:10.1002/(SICI)15206793(200007)17:7

Mcknight, D. H., \& Chervany, N. L. (2002). What trust means in e-commerce customer relationships : An interdisciplinary conceptual typology. International Journal of Electronic Commerce, 6(2), 35-59. doi:10.1080/10864415.2001.11044235

Moe, W. W., \& Trusov, M. (2011). The value of social dynamics in online product ratings forums. Journal of Marketing Research, 48(3), 444-456. doi:10.1509/jmkr.48.3.444

Moon, S., Park, Y., \& Seog Kim, Y. (2014). The impact of text product reviews on sales. European Journal of Marketing, 48(11/12), 2176-2197. doi:10.1108/EJM-06-2013-0291

Mudambi, S. M., \& Schuff, D. (2010). What makes a helpful online review? A study of customer reviews on Amazon. com. MIS quarterly, 34(1), 185-200. Retrieved from http://www.misq.org

Nunn, B. 12 Statistics on customer reviews. August 2nd, 2010. Retrieved from

http://www.searchenginepeople.com/blog/12-statistics-on-customer-reviews.html

Nunnally, J. (1978). Psychometric theory (2nd ed.). New York: McGraw-Hill.

Nunnally, J., \& Bernstein. (1994). Psychometric theory (3rd ed.). McGraw-Hill, New York.

Nysveen, H., Pedersen, P. E., \& Thorbjørnsen, H. (2005). Intentions to use mobile services: antecedents and cross-service comparisons. Journal of the academy of marketing science, 33(3), 330-346. doi:10.1177/0092070305276149 
Okazaki, S. (2009). Social influence model and electronic word of mouth: PC versus mobile Internet. International Journal of Advertising, 28(3), 439. doi:10.2501/S0265048709200692

Olbrich, R., \& Holsing, C. (2011). Modeling consumer purchasing behavior in social shopping communities with clickstream data. International Journal of Electronic Commerce, 16(2), 1540. doi:10.2753/JEC1086-4415160202

Pan, Y., \& Zhang, J. Q. (2011). Born unequal: a study of the helpfulness of user-generated product reviews. Journal of Retailing, 87(4), 598-612. doi:10.1016/j.jretai.2011.05.002

Park, D.-H., Lee, J., \& Han, I. (2007). The effect of on-line consumer reviews on consumer purchasing intention: the moderating role of involvement. International Journal of Electronic Commerce, 11(4), 125-148. doi:10.2753/JEC1086-4415110405

Pavlou, P. A. (2003). Consumer acceptance of electronic commerce: integrating trust and risk with the technology acceptance model. International Journal of Electronic Commerce, 7(3), 101-134. doi:10.1080/10864415.2003.11044275

Pavlou, P. a., \& Gefen, D. (2004). Building effective online marketplaces with institution-based trust. Information Systems Research, 15(1), 37-59. doi:10.1287/isre.1040.0015

Phelps, J. E., Lewis, R., Mobilio, L., Perry, D., \& Raman, N. (2004). Viral marketing or electronic word-of-mouth advertising: Examining consumer responses and motivations to pass along email. Journal of Advertising Research, 44(04), 333-348. doi:10.1017/S0021849904040371

Remenyi, D. Williams, B. and Money, A. (1998), Doing research in business and management: an introduction to process and method, Sage, UK.

Reynolds, N., \& Ruiz de Maya, S. (2013). The impact of complexity and perceived difficulty on consumer revisit intentions. Journal of Marketing Management, 29(5-6), 625-645. doi:10.1080/0267257X.2013.774290

Schindler, R.M. and Bickart, B. (2005), "Published word of mouth: referable, consumer-generated information on the Internet", Haugtvedt, C.P., Machleite K.A., and Yalch, R., Online consumer psychology: Understanding and influencing consumer behavior in the virtual world, London, pp. 35-61. Retrieved from http://camden-

sbc.rutgers.edu/FacultyStaff/research/schindler/Schindler\%20\%26\%20Bickart\%20\%282005\%2 9.pdf

Sen, S., \& Lerman, D. (2007). Why are you telling me this? an examination into negative consumer reviews on the web. Journal of interactive marketing, 21(4), 76-94. doi:10.1002/dir.20090

Shukla, P. (2014). The impact of organizational efforts on consumer concerns in an online context. Information \& Management, 51(1), 113-119. doi:10.1016/j.im.2013.11.003

Standifird, S. S. (2001). Reputation and e-commerce: eBay auctions and the asymmetrical impact of positive and negative ratings. Journal of Management, 27(3), 279-295. doi:10.1177/014920630102700304

Suh, B., \& Han, I. (2003). The impact of customer trust and perception of security control on the acceptance of electronic commerce. International journal of electronic commerce, 7(3), 135161. doi:10.1080/10864415.2003.11044270

Sun, T., Youn, S., Wu, G., \& Kuntaraporn, M. (2006). Online word of mouth (or mouse): an exploration of its antecedents and consequences. Journal of Computer Mediated Communication, 11(4), 1104-1127. doi: 10.1111/j.1083-6101.2006.00310.x 
Teo, T. (2014). Modelling Facebook usage among university students in Thailand: the role of emotional attachment in an extended technology acceptance model. Interactive Learning Environments, (ahead-of-print), 1-13. doi:10.1080/10494820.2014.917110

Teo, T. S. H., Lim, V. K. G., \& Lai, R. Y. C. (1999). Intrinsic and extrinsic motivation in Internet usage. Omega, 27(1), 25-37. doi:10.1016/S0305-0483(98)00028-0

Tirunillai, S., \& Tellis, G. J. (2012). Does chatter really matter? Dynamics of user-generated content and stock performance. Marketing Science, 31(2), 198-215.

doi:10.1287/mksc.1110.0682

Trivedi, J. P., \& Kumar, S. (2014). Determinants of Mobile Commerce Acceptance amongst Gen Y. Journal of Marketing Management, 2(2), 145-163. Retrieved from http://aripd.org/journals/jmm/Vol_2_No_2_June_2014/9.pdf

Tung, F.-C., Chang, S.-C., \& Chou, C.-M. (2008). An extension of trust and TAM model with IDT in the adoption of the electronic logistics information system in HIS in the medical industry. International journal of medical informatics, 77(5), 324-35. doi:10.1016/j.ijmedinf.2007.06.006

Van Dolen, W. M., Dabholkar, P. a., \& de Ruyter, K. (2007). Satisfaction with online commercial group chat: the influence of perceived technology attributes, chat group characteristics, and advisor communication style. Journal of Retailing, 83(3), 339-358. doi:10.1016/j.jretai.2007.03.004

Venkatesh, V. (2000). Determinants of perceived ease of use: integrating control, intrinsic motivation, and emotion into the technology acceptance model. Information systems research, 11(4), 342365. doi:10.1287/isre.11.4.342.11872

Vijayasarathy, L. R. (2004). Predicting consumer intentions to use on-line shopping: the case for an augmented technology acceptance model. Information \& Management, 41(6), 747-762. doi:10.1016/j.im.2003.08.011

Wang, E. S.-T. (2010). The effects of browsing frequency and gender on the relationship between perceived control and patronage intentions in e-tail. International Journal of Electronic Commerce, 14(3), 129-144. doi:10.2753/JEC1086-4415140306

Wang, E. S.-T. (2014). Perceived control and gender difference on the relationship between trialability and intent to play new online games. Computers in Human Behavior, 30, 315-320. di:10.1016/j.chb.2013.09.016

Wang, M.-S., Chen, C.-C., Chang, S.-C., \& Yang, Y.-H. (2007). Effects of online shopping attitudes, subjective norms and control beliefs on online shopping intentions: A test of the theory of planned behaviour. International Journal of Management, 24(2). Retrieved from http://onlinelibrary.wiley.com/journal/10.1111/\%28ISSN\%291468-2370

Wang, Y., Yu, Q., \& Fesenmaier, D. R. (2002). Defining the virtual tourist community: implications for tourism marketing. Tourism management, 23(4), 407-417. doi:10.1016/S02615177(01)00093-0

Wolfinbarger, M., \& Gilly, M. C. (2001). Shopping online for freedom, control, and fun. California management review, 43(2). Retrieved from http://search.proquest.com/docview/216150949?accountid=14494 
Wu, J., \& Liu, D. (2007). The effects of trust and enjoyment on intention to play online games. Journal of electronic commerce research, 8(2). Retrieved from http://jecr.org/sites/default/files/08_2_p02.pdf

Xiaorong, F., Bin, Z., Qinghong, X., Liuli, X., \& Yu, C. (2011). Impact of quantity and timeliness of EWOM information on consumer's online purchase intention under $\mathrm{C} 2 \mathrm{C}$ environment. Asian Journal of Business Research Volume, 1(2), 37-52. Retrieved from http://ssrn.com/abstract=2345694

Yang, F. X. (2013). Effects of restaurant satisfaction and knowledge sharing motivation on eWOM intentions: the moderating role of yechnology acceptance factors. Journal of Hospitality \& Tourism Research, 18, 1-35. doi:1096348013515918.

Ye, Q., Law, R., Gu, B., \& Chen, W. (2011). The influence of user-generated content on traveler behavior: An empirical investigation on the effects of e-word-of-mouth to hotel online bookings. Computers in Human Behavior, 27(2), 634-639. doi:10.1016/j.chb.2010.04.014

Zhao, Y., \& Lavin, M. (2012). An Empirical Study Of Knowledge Transfer In Working Relationships With Suppliers In New Product Development. International Journal of Innovation Management, 16(02). doi:10.1142/S1363919612003782

Zhou, T. (2012). Examining location-based services usage from the perspectives of unified theory of acceptance and use of technology and privacy risk. Journal of Electronic Commerce Research, 13(2), 135-144. Retrieved from http://www.csulb.edu/web/journals/jecr/issues/20122/paper3.pdf 